\title{
Artisanal or Industrial Conflict Minerals? Evidence from Eastern Congo
}

\author{
By NiK Stoop, MariJKe VerPoorten AND Peter VAN DER WindT
}

\section{June 2019}

Nik Stoop: Institute of Development Policy, University of Antwerp; Centre for Institutions and Economic Performance, University of Leuven; Southern Africa Labor and Development Institute, University of Cape Town; nik.stoop@ uantwerp.be; phone: +32 16324546.

Marijke Verpoorten: Institute of Development Policy, University of Antwerp; marijke.verpoorten@uantwerp.be.

Peter van der Windt: Division of Social Sciences, New York University Abu Dhabi; petervanderwindt@nyu.edu.

Published in World Development: 2019, 122, 660-674.

\section{Acknowledgements}

We are grateful to Dominic Parker, Joachim de Weerdt, Jo Swinnen, Tom de Herdt and two anonymous reviewers for valuable comments. We thank IPIS and CAMI for sharing data. We also thank participants in Bukavu (Workshop on the Governance of Natural Resources), Gent (Mining in Comparative Perspective: trends, transformations and theories), Cape Town (SALDRU seminar), and Verona (18th Jan Tinbergen Peace Science Conference). Nik Stoop benefitted from a scholarship from Research Foundation Flanders (Nr. 11Q2816N). We also benefitted from research grants from Research Foundation Flanders (Research Grant 1517614N and EOS Project 30784531). 
For many countries, resources have turned out to be a curse rather than a blessing (e.g. Collier and Hoeffler 1998, 2004; Fearon and Laitin 2003; Fearon 2005; Humphreys 2005; Ross 2006; Lujala 2010). Resources seem to be cursed also at the subnational level, with local mineral extraction shown to increase the risk of local conflict (Berman et al., 2017). However, to date, we know very little about how different modes of mineral extraction relate to local conflict.

There are two main ways to extract minerals: artisanal mining (ASM) and industrial largescale mining (LSM). ASM refers to a largely manual mode of extraction, practiced by individuals, groups or communities. ${ }^{1}$ LSM refers to a mechanized mode of production, practiced by large, often international, companies. These two forms of mineral extraction are very different. ASM provides working opportunities for millions of families around the world. In contrast, LSM is highly capital-intensive (World Bank, 2009). Furthermore, while ASM is intimately connected with the livelihoods of local communities, LSM may disrupt local communities and generally only has weak forward and backward linkages with the local economy (Banchirigah, 2008; Bazillier and Girard, 2019; Carstens and Hilson, 2009). Finally, ASM activities are often controlled and taxed by local elites (or warlords). Companies that undertake LSM activities, on the other hand, often maintain close relations with national elites (Geenen, 2014). Because of these differences, ASM and LSM are likely to relate very differently to conflict.

\footnotetext{
${ }^{1}$ The term ASM incorporates both artisanal and small-scale mining. In small-scale mining, mineral extraction is partly mechanized and may involve small companies. In this study, the abbreviation ASM refers to artisanal mining only.
} 
This study uses subnational data to investigate how artisanal and industrial mining affect local conflict in the Democratic Republic of Congo (DRC). We build on detailed, geo-referenced information on 2,026 artisanal mining sites, 3,696 industrial mining concessions and 6,542 conflict events in Eastern Congo. Among the conflict events, we distinguish between battles between armed groups, violence against civilians, looting and riots. The units of observation are $25 \times 25$ kilometer grid cells, and we exploit within-cell variations over time. Our empirical strategy takes advantage of two sources of variation that affected the Congolese mining sector between 2004 and 2015. ${ }^{2}$ First, we exploit variations in world mineral prices, providing us with variation to the value of Congolese mining sites. Second, the introduction of a new DRC Mining Code and Mining Regulations led to a surge in the granting of industrial mining concessions. Below, we will discuss in detail how both types of variation can be taken as plausibly exogenous.

We highlight two sets of results. First, exploiting variation in world mineral prices, we find that a rise in the value of artisanal mining sites increases the incidence of battles between armed actors, violence against civilians and looting. In sharp contrast, a rise in the value of industrial mining concessions has little to no significant impact on local-level conflict. We interpret the former result as a rapacity effect: armed actors intensify their fighting efforts over the increased

\footnotetext{
${ }^{2}$ The period under study is dictated by the availability of data on mining. We start the analysis in 2004 because we lack reliable information on mining activities before the end of the two Congo wars (1996-1998 and 1998-2003). We end in 2015, because our most recent data on mining cover the period up to and including 2015.
} 
value of ASM extraction sites. The absence of a similar effect for LSM suggests that companies are able to protect their concession against rapacious armed groups.

The second set of results relates to the expansion of LSM. Here we obtain three distinct results. First, in line with a protection effect, we find that the expansion of industrial mining decreases the incidence of battles between armed actors. Second, the expansion of industrial mining triggers an increase in riots, which most likely reflects responses by local communities who are often adversely affected by such expansions. Finally, we find that an expansion of industrial mining into areas already in use for artisanal mining increases the incidence of violence against civilians and looting. Here, our interpretation is that groups who previously profited from artisanal mining, notably artisanal miners (as workers) or armed actors (as taxers), turn to alternative sources of finance by looting and attacking civilians. This is akin to an opportunity cost and crime displacement effect, respectively. Note that these three LSM-related impacts on conflict only materialize when companies expand their activities from the research to the production phase. LSM research activities are not found to be significanlty associated with local conflict events.

Our study adds to a large empirical literature that has investigated the nexus between natural resources and conflict. The majority of these studies have examined the variation in resources and conflict across countries (e.g. Collier and Hoeffler 1998, 2004; Fearon and Laitin 2003; Fearon 2005; Humphreys 2005; Ross 2006; Lujala 2010) or used panel data with country fixed effects to examine intertemporal variations at the country-level (e.g. Bazzi and Blattman 2014; 
Cotet and Tsui 2013; Lei and Michaels 2014). ${ }^{3}$ These studies are not able to account for withincountry heterogeneity. This is an important gap because natural resources and conflict events tend to be clustered in space and are often concentrated in particular areas within a country. In response, a small but growing literature has used subnational data to study the relationship between natural resources and conflict (Angrist and Kugler, 2008; Berman et al., 2017; Dube and Vargas, 2013; Maystadt et al., 2014; Sanchez de la Sierra, 2019). To identify causal effects, these studies have exploited exogenous variation in international commodity prices to estimate how conflict was differentially impacted across areas where these commodities are produced or extracted. Berman et al. (2017), for instance, use spatially disaggregated data for all of Africa between 1997 and 2010 to show that an increase in mineral prices increases the incidence of conflict around industrial mining concessions.

Our study makes two contributions to the existing literature. First, in contrast to previous studies, our data allow us to distinguish between artisanal and industrial mining. This is important. Berman et al. (2017), for example, explore the impact of a rise in the value of largescale mining sites on local conflict. However, since ASM and LSM activities tend to be spatially clustered, their findings may be driven by artisanal, rather than industrial mining. The authors acknowledge this: "the RMD [Raw Material Data] dataset does not survey small-scale (potentially illegally operated) mines. Because of spatial clustering of mineral deposits, our main explanatory variable must be interpreted as a proxy for the extraction area of a given

\footnotetext{
${ }^{3}$ Ross (2004), Blattman and Miguel (2010) and Van der Ploeg (2011) offer extensive reviews of this literature.
} 
mineral rather than as coding for a specific RMD-referenced mine." (Berman et al., 2017, p. 1577). We find that once we account for changes to the value of artisanal mines, a rise in the value of industrial mining concessions has little to no effect on local conflict, and conflict dynamics are driven by artisanal mining.

Second, while most studies have focused solely on the impact of changes in the value of mining sites, our data allow us to also study the impact of the expansion of industrial mining sites. By studying a period in which industrial mining dramatically expands, and thereby dislocates both local communities and artisanal miners, we can shed light on another dimension of the mining-conflict nexus. In particular, by documenting an increase in riots, violence against civilians and looting in the wake of an industrial mining expansion, we add a quantitative analysis to a thus far largely qualitative literature that highlights the tenuous relationship of industrial mining expansions with local communities and artisanal miners. ${ }^{4}$

In terms of policy, these contributions meet an important social question of relevance for many developing countries. While policymakers obviously cannot change the location of minerals, they have decision power over the extraction mode. In the DRC, as well as in many other developing countries, the policy pendulum has been swinging back and forth between both modes of mineral extraction (Campbell, 2009). The pendulum's movements are influenced by national interests and world mineral prices, but also by policy advice of international institutions such as the World Bank and the IMF. Often this advice is based on criteria related

\footnotetext{
${ }^{4}$ E.g. Banchirigah (2008); Bush (2009); Carstens and Hilson (2009); Geenen (2013); Hilson and Yakovleva (2007); Kilosho Buraye et al. (2017); van Puijenbroeck and Schouten (2013).
} 
to economic efficiency and does not take wider political economy considerations into account. Acemoglu and Robinson (2013, p. 173) fittingly state that "politics is largely absent from the scene". They argue that economic policies should take into account potential (violent) backlashes from political factors. The results of this study may help to bring politics onto the scene.

The remainder of the paper is structured as follows. In the next section, we present a brief overview of related literature. Section II anchors our study in the Congolese context and Section III presents the data. We present the estimating equations and identification strategy in Section IV, while Section V presents the results. Section VI provides an overview of robustness checks and Section VII concludes.

\section{Related literature}

To examine how artisanal and industrial mining relate to conflict, we exploit variation in world mineral prices and the expansion of industrial mining. These analyses are guided by a number of well-established theories and recent studies. We present an overview below.

\section{A. Mineral Prices and Conflict}

How may an increase in mineral prices affect local-level conflict? Economic theory yields two opposite predictions. On the one hand, an increase in the value of mineral deposits may incentivize armed actors to engage in violent appropriation, as there are larger spoils to be made from fighting (Grossman, 1999; Hirshleifer, 1991; Olsson, 2007). This so-called rapacity effect predicts that armed actors will intensify or re-allocate their fighting efforts to locations where 
resource rents can be extracted. Berman et al. (2017), for instance, show that an increase in mineral prices increased local-level conflict near industrial mining concessions throughout Africa. On the other hand, a price increase can also reduce conflict by increasing the opportunity cost to fight. This opportunity cost effect suggests that an increase in wages will draw labor away from criminal activities and rebellion (Becker, 1968; Grossman, 1991). Collier and Hoeffler (2004, 1998), for example, find that the risk of conflict is lower the more income is foregone in rebellion.

An increase in mineral prices may thus increase both the returns to conflict and the opportunity cost of conflict. Which effect dominates depends on whether the value of lootable wealth goes up by more or less than wages (Dal Bó and Dal Bó, 2011). Since offsetting wageeffects are larger for commodities that are relatively more labor-intensive, Dal Bó and Dal Bó (2011) predict that the opportunity cost effect dominates for labor-intensive commodities, and the rapacity effect for capital-intensive commodities. Dube and Vargas (2013) offer empirical evidence from Colombia in support of these contrasting effects. They find that an increase in the price of oil (a capital-intensive commodity) exacerbates conflict, but that in the case of coffee (a labor-intensive commodity), conflict increases following a price decrease.

Bazzi and Blattman (2014) provide additional nuance and argue that the opportunity cost effect for labor-intensive commodities may be mitigated if those commodities are taxed by rebel groups. For instance, in their study on Columbia, Angrist and Kugler (2008) show that an increase in the price of coca (a labor-intensive commodity) did not translate to a similar increase in wages, as the benefits were largely taxed away by combatants. Lootable wealth increased 
more than wages, and thus the rapacity effect dominated the opportunity cost effect and an increase in coca prices increased rather than decreased conflict.

Relatedly, Ross (2003) argues that rebel groups are more likely to benefit from laborintensive commodities than from capital-intensive commodities, exactly because the former have a higher 'lootability', which he defines as the ease by which they can be extracted by small groups of unskilled workers. According to this definition, mineral deposits that can be mined in an artisanal way are classified as 'lootable', while deep-shaft minerals suitable for industrial mining are classified as 'unlootable'. Based on evidence from 15 case studies, Ross (2003) argues that rebel groups are more likely to benefit from lootable resources, since any actor that controls the surroundings of the extraction site may use it for funding. In sum, the lootability of labor-intensive commodities erodes the opportunity cost effect.

Drawing on these insights, the first part of our analysis investigates how variation in world mineral prices affects local level conflict in the vicinity of both artisanal and industrial mining sites in Eastern Congo.

\section{B. Expansion of Large-Scale Mining and Conflict}

How may the expansion of industrial mining affect local conflict? Maystadt et al. (2014) study how the granting of industrial mining permits impacts conflict. The authors develop a model in which conflict negatively affects the profitability of mining activities, which gives mining companies incentives to keep fighting away from their concession. The authors label this dynamic the protection effect. Using data from the DRC, they find evidence in support of 
this effect: granting industrial mining permits increases conflict, but not in the vicinity of the mining concession.

This study extends Maystadt et al. (2014) in three important ways. First, like Berman et al. (2017), Maystadt et al. (2014) only explore the impact of industrial mining. In contrast, we show that it is of central importance to also consider artisanal mining and the interaction between both types of mineral extraction to understand conflict. Second, Maystadt et al. (2014) do not distinguish between permits for LSM research or production. As we will discuss in detail below, these two phases of industrial mining are distinct and have very different implications for conflict. Third, Maystadt et al. (2014) explore the impact of industrial mining on an aggregate measure of conflict events. However, there are good reasons to believe that different types of conflict may be differently affected by the presence and expansion of industrial mining. Instead of looking at aggregate conflict, we distinguish between four types of conflict: battles between armed actors, violence against civilians, looting and riots.

Riots are relevant to study in this context, since evidence from case studies in Sub-Saharan Africa indicates that the expansion of large-scale mining is associated with community dislocation and the halting of artisanal mining activities. ${ }^{5}$ The resulting discontent can boil over into protests and riots. It is also relevant to study how armed actors interact with each other and civilians. In the DRC, various armed actors profit from artisanal mining activities (see Section II). The arrival of industrial mining affects these profits, and thus the behavior of these actors.

\footnotetext{
${ }^{5}$ A qualitative literature investigates the expansion of LSM in various African countries, particularly in Ghana (Banchirigah, 2008; Bush, 2009; Hilson and Yakovleva, 2007), Tanzania (Carstens and Hilson, 2009) and the DRC (Geenen, 2013; Kilosho Buraye et al., 2017; Van Puijenbroeck and Schouten, 2013).
} 
Parker and Vadheim (2017), for instance, model the behavior of armed actors in the DRC by building on Olson's (1993) 'stationary bandit' metaphor. According to the metaphor, armed groups fill the power vacuum left by an absent state, establish a monopoly on violence and, in return for taxes, offer protection against violence, including their own. When the profitability of the ASM activities that they are taxing is negatively affected, stationary bandits look for other sources of income, possibly turning into 'roving bandits'; e.g. by looting and pillaging civilians or by engaging in battles with other armed actors over more profitable mining sites (Laudati, 2013; Parker and Vadheim, 2017; Seay, 2012).

\section{Mining and Conflict in Eastern Congo}

\section{A. Context}

The DRC is a textbook case when it comes to the resource curse. Its untapped deposits of raw minerals are estimated to be worth US\$24 trillion (UNEP, 2011), but the majority of its population is dismally poor, mainly because of war and bad governance. This study focusses on Eastern Congo, which consists of the eleven provinces highlighted in Panel A of Figure 1. This part of the country is home to a large number of artisanal mining sites and industrial mining concessions. Eastern Congo was also home to the start of the First and Second Congo Wars (1996-1997 and 1998-2003). ${ }^{6}$ The latter directly involved eight African nations and 25 armed

\footnotetext{
${ }^{6}$ Both wars are described and discussed at length in, among others, Autesserre (2010), Reyntjens (2010), and Stearns (2011).
} 
groups, and has been named the deadliest war in modern African history (IRC, 2007). Despite the formal end to the war in July 2003, much of Eastern Congo continues to experience conflict. During the colonial period, mineral deposits in the DRC were mined industrially. Artisanal mining became more popular after 1982 when Mobutu liberalized the exploitation and trade in minerals. This liberalization was presented as a way for Congolese nationals to benefit from their country's natural resources (Geenen, 2014). In response, an increasing number of artisanal miners started extracting minerals using simple hand tools such as hammers and picks. During the two Congo wars, ASM continued to expand but LSM came to a standstill. Presently, ASM is an important livelihood strategy. The World Bank (2008) puts employment in DRC's artisanal mining sector in the range of 0.8 to 2 million individuals. Using an average of four to five dependents for each miner, this implies that up to 10 million people, or 16 percent of DRC's population, are dependent on artisanal mining for their livelihood (World Bank, 2008, p. 7).

The ASM-based livelihood, however, is under pressure. In 2002 and 2003, a new Mining Code and Mining Regulations were developed under the guidance of the World Bank and the IMF. The new Code and Regulations prioritized LSM for tax reasons and was therefore designed to attract international industrial mining companies (Mazalto, 2005). ${ }^{7}$ As a result, large-scale mining increased in importance and has been the major driver of DRC's GDP

\footnotetext{
${ }^{7}$ Artisanal miners are largely able to escape official taxation. According to the World Bank $(2008,56)$ : "when compared to official statistics of gold production [...], it would appear that more than half of DRC gold production is smuggled out of the country." In 2018, a new Mining Code was signed into law after a reform process that was initiated in 2012. The new Code is a modification, not a replacement, of the 2002 Code. Among the main innovations are an increase in royalties and taxes, intended to increase revenues for the Congolese State. The new Code also intends to increase benefits to local communities, including a required minimum contribution of 0.3 per cent of turnover to development projects for communities affected by a mine's activities (Loi n $18 / 001$ du 09 mars 2018 modifiant et complétant la Loi n ${ }^{\circ} 007 / 2002$ du 11 juillet 2002 portant Code minier).
} 
growth (African Economic Outlook, 2014). In 2013, mineral rents accounted for an estimated 18.6\% of GDP, up from 6.5\% in 2006 and $0.2 \%$ in 2002 (World Bank, 2016). ${ }^{8}$ Concurrently, government revenue from the minerals sector increased, reaching a record high of US\$1.4 billion in 2011, corresponding to about $10 \%$ of total government revenue (EITI, 2014).

Although the Mining Code recognizes ASM as a valid production mode, it specifies that artisanal activities should take place in clearly demarcated Artisanal Exploitation Zones (AEZ). In practice, very few AEZs were created and the Code includes a provision to close them down if "a new deposit which does not lend itself to artisanal mining has been discovered". 9 Consequently, industrial mining companies legally have the upper hand, while artisanal mining largely takes place outside the state's regulatory framework.

Artisanal mining in Eastern Congo does not only involve miners. In about 56\% of ASM sites, armed actors are present on a permanent or regular basis (Weyns et al., 2016). The Congolese army is present in $38 \%$ of ASM sites, while in $25 \%$ of sites the armed presence consists of various rebel groups and local self-defense militias ("Mai-Mai groups"). ${ }^{10}$ These armed actors profit from ASM through illegal taxation. They also undertake other activities for income, such as trading minerals and commodities (such as beer, cigarettes, cannabis or palm oil), forcing artisanal miners to work for them, and looting villagers. ${ }^{11}$

\footnotetext{
${ }^{8}$ FDI to DRC increased from 1.6\% of GDP in 2002 to $11 \%$ in 2007 (World Bank, 2016).

${ }^{9}$ DRC Mining Code 2002, Title 4, Chapter 1, Article 110.

${ }^{10}$ For detailed information on armed actors in Eastern Congo see e.g. Stearns (2013a, 2013b), Stearns and Vogel (2015), Vlassenroot (2013) and Vogel and Mvano (2016).

${ }^{11}$ E.g. Global Witness (2016); Laudati (2013); Schouten et al. (2017); Seay (2012); Weyns et al. (2016).
} 
Case study evidence suggests that industrial mining activities in Congo are also associated with conflict, but less so related to armed actors and more so related to tensions with local communities. To protect their investments from armed actors, industrial mining companies in Eastern Congo tend to have a strong security apparatus. Besides their own private security forces, they are known to receive backing from the Congolese government and may count on armed support from the Congolese army and the mining police (Geenen, 2014, 2013; Kilosho Buraye et al., 2017). In addition, there are cases where mining companies cooperate directly with rebel groups in return for protection (Global Witness, 2016; Human Rights Watch, 2005).

While violence by armed actors in LSM sites is limited, qualitative research has documented that confrontations between mining companies and local communities are commonplace (Geenen, 2013; Kilosho Buraye et al., 2017; Van Puijenbroeck and Schouten, 2013). They occur at a specific tilting moment in the industrial activities, i.e. the transition from research to production activities. The first step for a mining company to operate in the DRC is to obtain a research permit, which gives the holder the right to carry out mineral exploration works. During the research phase, communities residing within the boundaries of the concession can generally remain where they are, and artisanal mining is still tolerated. In order to extract minerals, the company needs to transform its research permit into a production permit. When a company moves to the production phase, local communities often have to be relocated, and artisanal miners have to cease their activities. Local communities and artisanal miners in response often (violently) defend their 'customary right' to occupy the land and dig for minerals. 


\section{B. Sources of Variation}

To examine how artisanal and industrial mining relate to local conflict, this study exploits two sources of variation that affected the Congolese mining sector between 2004 and 2015.

First, we make use of variation in world mineral prices. The main minerals extracted in Eastern Congo are tin, tungsten and tantalum - often referred to as the 3Ts - gold, and copper. On average, the world prices of these minerals tripled over the period under study (see Panel A of Figure 2). A troy ounce of gold, for instance, was on average valued at $\$ 326$ in 2004, while it was worth $\$ 1,160$ in 2015 in constant 2015 US dollars. This boom in mineral prices is generally explained by an increasing demand in emerging economies, particularly China (Canuto, 2014; Humphreys, 2010). As mineral traders in Eastern Congo closely monitor world mineral prices and use them to set local prices, the boom strongly increased the value of mineral deposits in both the ASM and LSM mines in our study area (Geenen, 2014).

Second, in response to the adoption of the 2002 Mining Code and 2003 Mining Regulations the number of LSM research and production concessions increased considerably in subsequent years. The total number of granted research permits increased from 237 to 3,368 between 2004 and 2015, while the total number of granted production permits increased from 82 to 327 (see Panel B of Figure 2).

We are interested in estimating how these sources of variation affected local conflict events in Eastern Congo. Section IV discusses the identification strategy in detail. 


\section{Data}

\section{A. Data Sources}

Conflict. - To measure local conflict, we build on the Armed Conflict Location and Event Data Project (ACLED). ACLED provides information on the precise date and location of conflict events in 60 countries, including the DRC. Information on the events is mainly collected from local, regional and national news sources, as well as reports from humanitarian agencies. The data are described in detail by Raleigh et al. (2010), and have been widely used in recent academic research (e.g. Berman et al. 2017; Minoiu and Shemyakina 2014; Maystadt and Ecker 2014; Besley and Reynal-Querol 2014; Michalopoulos and Papaioannou 2016). The ACLED database combines two important features. First, it captures low-intensity conflict events that take place both within and outside the context of civil war, without setting a threshold for battle-related deaths. Second, conflict events are not limited to battles between armed actors, but cover a wide variety of conflict types, including violence against civilians and riots. $^{12}$

When exploring the impact of changes in the value of mining sites, we focus on the two main types of conflict recorded by ACLED: battles between armed actors and violence against civilians. A battle is defined as "a violent interaction between two politically organized armed groups at a particular time and location" (Raleigh and Dowd 2016: p.10), where armed groups

\footnotetext{
${ }^{12}$ ACLED thus offers two important advantages over the Uppsala Conflict Data Program Georeferenced Events Dataset (UCDP GED), which has a narrower focus on civil war, and only covers deadly events for conflicts that surpass the threshold of 25 battle-related deaths per year (Sundberg and Melander, 2013). Moreover, it does not report on riots or protests.
} 
include both rebel movements and the Congolese army. The database contains 2,799 battle events that occurred in Eastern Congo between 2004 and 2015. Violence against civilians occurs when these armed groups attack civilians. The database contains 2,530 such events for our study area and period. In addition, when exploring the expansion of LSM, we analyze two additional types of conflict. First, because LSM expansion may engender grievances among local communities, we consider riots. Riots are coded by ACLED as potentially violent public demonstrations by groups. We have information on 518 riot events. Second, because the expansion of LSM may necessitate armed groups (or artisanal miners) to find other sources of income, we also explore looting of civilians. We follow Parker and Vadheim (2017) and consider an ACLED conflict event as looting if an armed group's actions are described by the words 'loot', 'pillage', 'plunder', 'rob', 'steal', 'ransack', 'sack', or 'seize'. ${ }^{13}$ In total, we have information on 718 looting events.

Mining.- Information about artisanal mining comes from the International Peace Information Service (IPIS). In collaboration with the Congolese Ministry of Mines and other local stakeholders ${ }^{14}$, IPIS research teams mapped the artisanal mining sites in Eastern Congo. The data were collected between 2008 and 2015 and contain the location and type of mineral extracted for 2,026 artisanal mining sites. The data and collection process are described in detail

\footnotetext{
${ }^{13}$ Examples of looting events include "FDLR rebels established a base for looting gold and cassiterite from the mines at Kasiyiro"; and "Soldiers erected illegal barriers at Mangi and Panga mining sites in Banalia area since the beginning of June, extorting and seizing goods from mine workers and merchants". The majority of looting events (73\%) are coded as violence against civilians by ACLED.

${ }^{14}$ Other local stakeholders include: the Congolese Mining Registry; the Congolese Public Service for Assistance to Artisanal and Smallscale Mining; the provincial Mining Divisions and local civil society organizations.
} 
in Weyns et al. (2016). While the database does not record the opening date of mining sites, IPIS presumes that the large majority of sites existed before 2004, the onset of our study period (personal communication with IPIS). ${ }^{15}$

To learn about industrial mining concessions, we rely on a dataset of the Congolese Mining Registry (CAMI). CAMI is a public entity under the supervision of the Congolese Ministry of Mines and oversees the granting and renewal of LSM research and production permits. The CAMI dataset provides detailed information on the geographic boundaries of all LSM concessions. It further records the exact granting dates of mining permits, whether the permit is for mineral research or production, and what minerals are envisaged to be extracted. For our study area and period, we have information on 3,696 concessions.

Mineral prices. - Finally, we obtain monthly time-series data on international mineral prices from metalprices.com. We focus on the dominant minerals used in ASM and LSM in Eastern Congo: gold, tin, tantalum, tungsten and copper. Gold prices are reported in US dollars per troy ounce. Prices for 3T minerals and copper are reported in US dollars per pound.

\section{B. Descriptive Statistics}

We impose a grid with cells of 25 x 25 km over Eastern Congo (see Panel B of Figure 1). Our database counts 144 monthly observations for 2,176 grid cells. There are three reasons why we

\footnotetext{
${ }^{15}$ The data on artisanal mining sites in Eastern Congo collected by Sanchez de la Sierra (2019) corroborate this claim. In North-Kivu he sampled all communities with mining activities, while in South-Kivu he sampled all coltan-mining communities and a random subset of goldmining communities. Of the 411 artisanal mining sites in his sample, only one coltan site was opened during the period of his study (19952013), while the others already existed before. Moreover, the minerals in none of these sites were exhausted before the end of his study.
} 
use grid cells as the unit of analysis, rather than administrative areas. First, we are interested in studying the local-level relationship between mining and conflict. The cells that we study cover $625 \mathrm{~km}^{2}$ and are large enough to encompass industrial mining concessions while being small enough to allow us to focus on the near vicinity of the extraction sites. ${ }^{16}$ Second, while the boundaries of administrative areas may be endogenous to conflict, this is not the case for the grid cells that we impose. Third, we follow other studies that have also used spatially disaggregated grid cells in the analysis of conflict events (see e.g. Berman et al., 2017; Parker and Vadheim, 2017; Besley and Reynal-Querol, 2014; Buhaug and Rød, 2006). Summary information at the level of the grid cells can be found in Table 1. Figure 3 maps the location of conflict events, ASM sites and LSM concessions.

Conflict.- Panels A and B of Figure 3 offer a geographical presentation of our conflict data. Table 1 indicates the share of grid cells that witnessed battles (13\%), violence against civilians $(14 \%)$, riots $(5 \%)$ and looting $(7 \%)$ over the 144 -months period of study. It further shows the number of months during which these conflict events occurred within a cell: the maxima are 68 for battles, 59 for violence against civilians, 44 for riots and 26 for looting. Since the econometric analysis is based on cell-month observations, Table 1 also indicates the overall monthly probability of battles $(0.5 \%)$, violence against civilians $(0.5 \%)$, riots $(0.1 \%)$ and looting $(0.2 \%)$ in a cell.

\footnotetext{
${ }^{16}$ The DRC Mining Code limits the size of an LSM research permit to $400 \mathrm{~km}^{2}$ (DRC Mining Code 2002, Title 3, Chapter 1, Article 53). The average LSM research permit in our sample covers $190 \mathrm{~km}^{2}$, while the average production permit has a surface area of $104 \mathrm{~km}^{2}$. In choosing the size of the cells, we follow Parker and Vadheim (2017) who provide a robustness check of their results using grid cells of approximately $25 \times 25$ kilometers.
} 
Mining.- Panel C of Figure 3 shows the location of artisanal mining sites as they emerged from IPIS' mapping exercise. About 14\% of the grid cells contain ASM sites. Gold and 3T are by far the most important minerals: $68 \%$ of ASM sites contain gold, while $29 \%$ contain at least one of the $3 \mathrm{~T}$ minerals. ${ }^{17}$ The number of gold mines in a cell varies between zero and fifty, while the number of $3 \mathrm{~T}$ mines varies between zero and thirty. Only about $2 \%$ of cells contain both ASM gold and 3T sites.

Panel D of Figure 3 maps the information from CAMI. It shows the LSM concessions covered by a research or production permit during the period of our study. The majority of LSM permits (80\%) cover gold or one of the $3 \mathrm{~T}$ minerals, while copper (16\%) also accounts for a considerable share. ${ }^{18}$ It also shows the Artisanal Exploitation Zones, where ASM should take place according the Congolese Mining Code. The zones, however, are hardly visible on the map: only 177 AEZs have been created in Eastern Congo, covering a mere $1 \%$ of the total mineral concession surface area.

When combining information from the IPIS and CAMI databases, we find that less than $1 \%$ of the artisanal miners registered by IPIS operate in an AEZ. About 29\% of the ASM sites are located on an LSM research concession and about 32\% are located on an LSM production concession; the remaining sites are located in areas that are not covered by a mining permit.

\footnotetext{
${ }^{17}$ Only $3 \%$ of ASM mines extract other minerals, mostly diamonds. However, all grid cells with ASM sites are dominated by either gold or $3 \mathrm{~T}$ mining.

${ }^{18}$ The remaining 4\% of LSM companies mainly extract diamonds, but diamonds are the main LSM mineral in only $0.1 \%$ of the grid cells.
} 
Combined with evidence from the case studies presented in Section II.A, it is thus pertinent to explore not only the separate impact of artisanal and industrial mining, but also their interaction.

Sources of variation.- Our analysis exploits variation in the world mineral price of gold, tin, tungsten, tantalum and copper. Panel A of Figure 2 shows the monthly price evolution for gold, 3T minerals and copper from 2004 to 2015, revealing a clear upward trend.

To capture the expansion of large-scale mining, we calculate - for each cell-month observation - the share of the surface area that is covered by an LSM concession. We distinguish between concessions with a permit for research or production activities. When considering the entire period of study (2004-2015), 28\% of the average cell is covered by a research concession, while $2 \%$ is covered by a production concession (Table 1).

\section{Estimating Equations and Identification Strategy}

\section{A. Increase in Mineral Prices}

We are interested in estimating causal effects, but the value of artisanal and industrial mining sites is not randomly assigned. To identify impact, this study follows several recent studies that exploit the fact that fluctuations in world mineral prices provide plausible exogenous variation to the value of mining sites (Berman et al., 2017; Dube and Vargas, 2013; Maystadt et al., 2014;

Sanchez de la Sierra, 2019). We estimate the following equation, which follows Berman et al. (2017) but separates out the effects for both modes of mineral extraction:

$$
\text { Conflict }_{i t}=\delta_{i}+\mu_{t}+\beta_{1} A S S M_{i}^{*} \text { price }_{t}+\beta_{2} \text { LSM }_{i} * \text { price }_{t}+\varepsilon_{i t}
$$


, where Conflict $t_{i t}$ is a dummy variable for one of two dependent variables: battles between armed actors or violence against civilians in grid cell $\mathrm{i}$ and month $\mathrm{t} .{ }^{19}$ To control for time-invariant cell-specific determinants of conflict events (e.g. geography) we introduce cell fixed effects $\delta_{\mathrm{i}}$. We also introduce month fixed effects, $\mu_{\mathrm{t}}$, to control for all time-varying common shocks and trends that may impact conflict events and mining activities in Eastern Congo as a whole.

The interaction term $\mathrm{ASM}_{\mathrm{i}}$ * price $\mathrm{t}_{\mathrm{t}}$ captures changes in the value of ASM sites. It equals the monthly world price for the ASM mineral (gold, tin, tungsten or tantalum) that has the most mining sites in cell i. ${ }^{20}$ Hence, in a cell where artisanal gold mining dominates, it equals the monthly price of gold. In a cell where artisanal tantalum mining dominates, it equals the monthly price of tantalum. In a cell without ASM mines, the interaction term equals zero. The dominant ASM mineral does not change over time; the main terms of the interaction therefore drop out of the equation due to the inclusion of cell and month fixed effects. ${ }^{21}$ The interaction term $\mathrm{LSM}_{\mathrm{i}}$ * price $\mathrm{t}_{\mathrm{t}}$ captures changes in the value of LSM mines in the same way. Besides gold and 3T minerals, the LSM-price interactions also include copper. ${ }^{22}$

In the first part of our analysis, we single out the effect of mineral price variations and abstract from LSM expansions. To create a time invariant $\mathrm{LSM}_{\mathrm{i}}$ variable, we follow the same two

\footnotetext{
${ }^{19}$ In the main specifications, our dependent variables focus on conflict incidence. In Section VI, we explore various measures of conflict intensity.

${ }^{20}$ To facilitate interpretation of the results, mineral prices are standardized over the period of study such that the mean equals zero and the standard deviation equals one. All results are highly robust to defining the interaction as a weighted index, according to the relative importance of mineral $\mathrm{j}$ in cell $\mathrm{i}: \sum_{\mathrm{j}}$ share mineral $\mathrm{ij}_{\mathrm{j}}$, price $\mathrm{jt}_{\mathrm{j}}$. With a positive correlation of 0.94 (significant at the $99 \%$ significance-level), there is little difference between the two definitions of the price index.

${ }^{21}$ While being gradually crowded out by LSM - and having to downscale activities in certain locations - the ASM sites in our sample are active throughout the entire period, thus leaving the dominant ASM mineral unchanged.

${ }^{22}$ Diamonds are excluded since panel data on diamond prices are not available. This does not bias the results because diamonds are the main LSM mineral in only $0.1 \%$ of the grid cells.
} 
strategies as Berman et al. (2017). First, we only consider cells for which the LSM status did not change in the period of study; i.e. those cells in which LSM was either always or never present. Second, we consider all cells, but use a time-invariant dummy to indicate cells that have LSM presence at any point over the period 2004-2015.

The identifying assumption underlying equation (1) is that variation in world mineral prices provides us with exogenous variation in the value of artisanal and industrial mines in the locations where these minerals are extracted. In our context, this assumption rests on two conditions. First, world mineral prices should not be affected by local conflict events in Eastern Congo. This condition is reasonable, since the majority of ASM (68\%) and LSM (69\%) sites in our sample focus on the production of gold, for which the DRC supplies less than $1 \%$ of world production (USGS, 2013, 2015). One might argue, however, that it does not hold for tantalum, since production volumes for the DRC fluctuate between $10-20 \%$ of total world production (USGS, 2013, 2015). Cells dominated by tantalum mining represent about $6 \%$ of cells with ASM sites and about $0.6 \%$ of cells with LSM concessions. In Appendix 2 we show that our results remain stable when dropping these cells from the analysis.

A second condition for our identifying assumption to hold is that local Congolese mineral prices should follow international price trends. While we do not have detailed information on local mineral prices, Geenen (2014) shows that local mineral traders in Eastern Congo closely monitor world mineral prices and use them to set local prices. ${ }^{23}$ It is thus reasonable to assume

\footnotetext{
23 "Even small traders who are based near the mining sites say they regularly check the price online, on their phone, or on TV5 Afrique" (Geenen 2014: p.249). Geenen (2014: p.249) further quotes a local mineral trader stating that "Following the world market price is the least we can do. If you don't do it, you lose money".
} 
that the variation in world mineral prices translate to the value of both the ASM and LSM mines in our sample. ${ }^{24}$

We follow the previously-mentioned studies that exploit fluctuations in world mineral prices and estimate equation (1) using a Linear Probability Model. Coefficients $\beta_{1}$ and $\beta_{2}$ measure how variation in the value of ASM and LSM mines impacts local conflict.

Since conflict events and mining sites are both clustered in space, we apply the methodology developed by Conley (1999) and Hsiang, Meng, and Cane (2011), to correct the standard error, $\varepsilon_{\mathrm{it}}$, for both spatial correlation and location-specific serial correlation. Following Berman et al. (2017), we present specifications with a demanding correction that allows for spatial correlation within a radius of $500 \mathrm{~km}$ and a practically infinite horizon of serial correlation $(100,000$ months). In Section VI, we show that the results are robust to alternative specifications for the standard errors.

\section{B. Expansion of Large-Scale Mining}

In addition to looking at the impact of changing prices, we investigate how the expansion of large-scale mining affects local conflict in Eastern Congo. To do so we estimate the following equation:

\footnotetext{
${ }^{24}$ The period after the introduction of the US conflict minerals legislation embedded in the Dodd-Frank act (2010 and onwards) may provide a notable exception to the transmission from international to local mineral prices. We elaborate in Appendix 3 and show that: (1) our results remain stable when dropping this period from the analysis, and that (2) the impact of $\mathrm{ASM}_{\mathrm{i}}$ * price $\mathrm{t}$ on battles between armed actors is significantly reduced during the Dodd-Frank period.
} 


$$
\begin{aligned}
& \text { Conflict }_{i t}=\delta_{i}+\mu_{t}+\beta_{1} \text { ASM }_{i} * \text { price }_{t}+\beta_{2} \text { LSM Research }_{i t} * \text { price }_{t}+\beta_{3} \text { LSM Production }_{i t} * \\
& \text { price }_{t}+\beta_{4} \text { LSM Research }_{i t}+\beta_{5} \text { LSM Production }_{i t}+\varepsilon_{i t}
\end{aligned}
$$

Conflict $t_{i t}$ is again a dummy variable for the occurrence of a conflict event: battles between armed actors or violence against civilians in grid cell i and month t. To further explore the impact that an LSM expansion may have on the incentives of armed actors and local communities, we estimate equation (2) for two additional types of conflict: looting and riots. The expansion of large-scale mining is captured by the variables LSM Research ${ }_{\text {it }}$ and LSM Production $_{\text {it }}$, indicating the share of the cell-surface area covered by research or production concessions. Because concessions must first pass through the research phase, an increase in

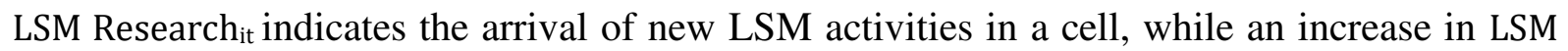
Production $_{\text {it }}$ indicates a move from the research to the production phase. We again control for changes in mineral prices. As before, the interaction term $\mathrm{ASM}_{\mathrm{i}}$ * price $\mathrm{t}_{\mathrm{t}}$ captures changes in the value of ASM sites. The interaction terms LSM Research ${ }_{i t}{ }^{*}$ price $_{t}$ and LSM Production it $^{*}$ price $_{t}$ now capture changes in the value of LSM research and production concessions, respectively. Note that the inclusion of these LSM-price interactions ensures that we evaluate the impact of the LSM expansion abstracting from changes in the value of LSM concessions. $\delta_{\mathrm{i}}$ and $\mu_{\mathrm{t}}$ are defined as before.

Case studies from the DRC and other African countries indicate that the start of LSM activities may be associated with rising tensions between the company and local communities, and particularly so in areas where artisanal mining takes place. To investigate the impact of the 
expansion of large-scale mining activities in areas where artisanal miners are active, we estimate equation (3),

$$
\begin{aligned}
& \text { Conflict }_{i t}=\delta_{i}+\mu_{t}+\beta_{1} \text { ASM }_{i} * \text { price }_{t}+\beta_{2} \text { LSM Research }_{i t} * \text { price }_{t}+\beta_{3} \text { LSM Production }_{i t} * \\
& \text { price }_{t}+\beta_{4} \text { LSM Research }_{i t}+\beta_{5} \text { LSM Production }_{i t}+\beta_{6} \text { LSMR in ASM }_{i t}+\beta_{7} \text { LSMP in ASM }_{i t} \\
& +\varepsilon_{i t}
\end{aligned}
$$

which adds two variables to equation (2): LSMR in ASM ${ }_{i t}$ and LSMP in ASM $_{i t}$. These variables capture the start of LSM research and production activities in areas within cell i where artisanal miners are active. Specifically, the variables indicate the number of artisanal mining sites encompassed by the LSM concessions.

Figure 4 illustrates how LSM activities may expand in a grid cell and interact with ASM. Light grey areas indicate concessions covered by an LSM research permit, dark grey areas indicate concessions covered by an LSM production permit, and black dots denote the location of ASM sites. In Panel A, the grid cell counts three ASM sites and LSM is not present. Moving to Panel B, an LSM research concession is added, which covers about one quarter of the cell's

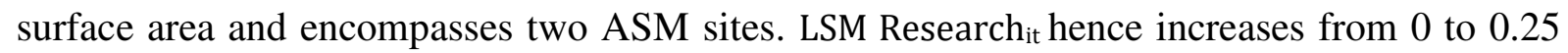
and LSMR in $\mathrm{ASM}_{\mathrm{it}}$ from 0 to 2. Moving to Panel C, an additional research concession is added,

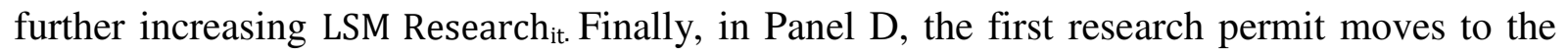
production phase, increasing LSM Production ${ }_{\text {it }}$ from 0 to 0.25 and LSMP in ASM $_{\text {it }}$ from 0 to $2 .{ }^{25}$

\footnotetext{
${ }^{25}$ Note that multiple research and production permits may be added in a cell from one month to the next, which may or may not encompass ASM sites. Overall, we find a rather weak negative correlation between LSM Research ${ }_{i t}$ and LSM Production $n_{i t}(-0.08)$, while LSMR in ASM and LSMP in $\mathrm{ASM}_{\mathrm{it}}$ are positively correlated (0.06).
} 
As before, we estimate equations (2) and (3) using a Linear Probability Model and correct the standard error, $\varepsilon_{i t}$, for spatial correlation and location-specific serial correlation.

Equations (2) and (3) aim to estimate the causal effect of LSM expansions. However, it is possible that the incidence of conflict affects the likelihood of LSM expansions. LSM companies may choose to invest in locations with little conflict, or at a time when conflict has abated. Note that such a reverse causality bias would only threaten our finding that LSM production expansion decreases battles, and not the findings LSM production expansion is associated with an increase in the incidence of violence against civilians, looting and riots (see section V. Results). These results would constitute lower bounds of the actual effect, rather than false positives.

Nevertheless, in Appendix 3, we provide a number of analyses suggesting that our results are not driven by reverse causality. First, the data patterns go against the idea that companies choose to invest in cells with lower conflict levels. Panel A of Figure A.2 compares battle incidence across cells that are eventually covered by either a research or a production permit, thus cells that include mineral deposits suitable for LSM. We find that battle incidence is generally higher, rather than lower, in cells where LSM companies decide to move from the research to the production phase. While the average monthly battle incidence equals $0.4 \%$ for cells with only research concessions, it equals $0.8 \%$ for cells with a production concession. Furthermore, Panel B of Figure A.2 shows the evolution of battle incidence in the 36 months before and after the installment of an LSM production concession. The graph suggests that battle incidence decreases after, rather than before, companies decide to move from the research to the 
production phase. The average monthly battle incidence equals $1.33 \%$ in the 36 months before the installment of an LSM production concession, but drops to $0.57 \%$ in the following 36 months.

Second, to further address the concern of reverse causality, we run three checks (results can be found in in Appendix 3). First, we include dynamic and spatial conflict lags, effectively controlling for conflict incidence in a cell and its surrounding cells up to one year before the LSM expansion. These lags capture the incidence of all types of conflict events, thus taking into account that past battles may affect future violence against civilians, or the other way around. ${ }^{26}$ Second, to account for the possibility that conflict in a specific region may have been trending up or down prior to the expansion of large-scale mining, we introduce provincespecific linear time trends. Third, we address the concern that cells where companies decide to invest may be different from other cells in ways that change over time and are therefore not entirely captured by the inclusion of cell fixed effects. To do so, we estimate equation (3) on the restricted sample of cells where companies eventually decided to move to the production phase. Reassuringly, the results regarding the expansion of LSM hold across all sensitivity checks (see Tables A.4-6).

\footnotetext{
${ }^{26} \mathrm{We}$ introduce the lags to check the robustness of our $\beta$ coefficients. The coefficients on these dynamic and spatial lags may be estimated with bias, to which we return in Appendix 4.
} 


\section{Results}

\section{A. Increase in Mineral Prices}

We first present results related to the impact of changes in mineral prices in artisanal and industrial mining areas on local conflict. To start, we estimate equation (1) focusing solely on exogenous increases in the value of LSM mines in order to mimic the set-up of Berman et al. (2017). The results are presented in Panel A of Table 2. We find similar results as Berman et al. (2017): a rise in mineral prices increases the incidence of conflict near industrial mines extracting those minerals. This result holds in the second specification, which applies a timeinvariant LSM dummy to the full sample of cells. Specifically, a one standard deviation rise in mineral prices increases the incidence of battles between armed actors and violence against civilians with 0.11 and 0.12 percentage points. These findings are statistically significant at the $5 \%$ and $1 \%$ significance level, respectively.

Next, in Panel B of Table 2, we move beyond Berman et al. (2017) and distinguish between different modes of mineral extraction. We highlight two results. First, we find strong evidence that increases in the value of ASM sites trigger conflict. Focusing on the second specification, we find that a one standard deviation rise in mineral prices increases the incidence of both battles and violence against civilians with 0.40 percentage points near ASM sites that extract these minerals. These findings are statistically significant at the $1 \%$ significance level. In cells with ASM, the average monthly incidence of conflict events equals $1.51 \%$ for battles and $1.26 \%$ for violence against civilians. The estimated coefficients imply that when ASM mineral prices 
rise by one standard deviation, the incidence of battles and violence increases with $26 \%$ and $32 \%$, respectively. ${ }^{27}$ Second, after controlling for the presence of nearby ASM sites, we find that the estimated coefficients on the LSM-price interactions are nearly halved in size and strongly lose significance. The results of an F-test further indicate that the estimated coefficients of the ASM and LSM price interactions are significantly different at the $1 \%$ significance level (see Table 2). Because artisanal and industrial mining are often located in the same areas, this result urges researchers interested in local conflict to take into account the mineral extraction type.

Our results indicate that in response to changes in the value of artisanal mines the rapacity effect seems to dominate the opportunity cost effect, while there are little to no effects for changes in the value of large-scale mines. Following Dal Bó and Dal Bó (2011), this suggests that an increase in the value of ASM sites has a stronger effect on lootable wealth than on wages. In Eastern Congo, this dynamic is likely. Various armed actors are known to profit from artisanal mining, thus taxing away potentially offsetting wage-effects from a mineral price increase. Besides raising taxes, the increased value of spoils likely incentivizes armed actors to fight for control of artisanal mines. Hence, the increase in battles. As argued by Parker and Vadheim (2017), and elsewhere in the literature, such a rapacity effect is likely to dominate when various competing armed actors are relatively homogenous in size and strength, increasing incentives to contest each other (Fearon, 1995; Hirshleifer, 1991). This power

\footnotetext{
${ }^{27}$ The magnitude of these effects is very close to those reported by Berman et al. (2017), who find that a one standard deviation increase in mineral prices leads to an increase in conflict incidence of around $30 \%$.
} 
symmetry applies well to artisanal mining in Eastern Congo, where mines are controlled by a plethora of relatively small groups of armed actors, with continuously changing allegiances, reorganizations and reincarnations (Stearns and Vogel 2015; Vogel and Mvano 2016; Weyns et al. 2016). Furthermore, apart from increasing competition between armed actors, an increase in lootable wealth may also create infighting within the group of armed actors that controls the resource, and both types of violence may spill over in increased violence against civilians (Ross, 2003).

In contrast to artisanal mines, these dynamics are less likely at play for industrial mines. There are a number of reasons to expect that the increase in value of industrial mining sites has little effect on local conflict. First, an increase in mineral prices has little effect on wages. LSM companies in Eastern Congo are capital-intensive and employ few local workers (Geenen, 2014, pp. 290-291). Those workers receive a fixed wage that is unlikely to fluctuate with mineral prices. ${ }^{28}$ Second, an increase in mineral prices also does not have large impact on lootable wealth available at LSM concessions. Indeed, it is reasonable to expect that LSM companies have incentives to protect their existing capital investments, whether mineral prices are low or high (Maystadt et al., 2014). The strong security apparatus of LSM companies - often enforced by private security forces, the Congolese army and the mining police - may further create a power asymmetry, making it less likely that they are challenged by other armed actors.

\footnotetext{
${ }^{28}$ In the general equilibrium framework of Dal Bó and Dal Bó (2011) an expansion of the capital-intensive sector would contract the laborintensive sector, making labor relatively more abundant, reducing wages and increasing the opportunity cost to fight. As argued by Bazzi and Blattman $(2014,6)$ : "This general equilibrium mechanism, however, would be moderated by labor market conditions that limit the responsiveness of wages in the lowest income countries to changes in the demand for labor in other sectors-e.g., large amounts of nonmarket labor, of highly elastic labor supply, or downward nominal wage rigidity".
} 


\section{B. Expansion of Large-Scale Mining}

Panel A of Table 3 presents the results for equation (2), focusing on the expansion of LSM. We distinguish between research and production permits, and also investigate the impact on two additional types of conflict: looting and riots. Panel B presents results for equation (3), extending Panel A by also investigating the interaction between ASM and LSM. We present both sets of results, but since they are highly comparable, we focus on the more inclusive specification of equation (3) in our discussion.

In line with the results for equation (1), we find no evidence that variation in the value of industrial mining concessions is significantly related to conflict incidence. We do again find such a relationship for ASM: a one standard deviation rise in mineral prices increases the incidence of battles, violence against civilians and looting with $0.40,0.37$ and 0.17 percentage points, respectively, around artisanal mines where these minerals are extracted (see Columns 5-7). These findings are significant at the 5\%,1\% and 5\%-level, respectively. Compared to the average monthly incidence of these conflict events in cells with ASM, the estimated coefficients imply an increase of $27 \%$ for battles, $29 \%$ for violence against civilians and $35 \%$ for looting. Mineral prices of gold and 3T rose by about two standard deviations over the period of our study, thus increasing the incidence of these conflict events by $54 \%$ to $70 \%$. We find no evidence that a rise in value of artisanal mines leads to more riots.

Moving to the impact of the expansion of LSM activities, we find no evidence that the start of LSM research activities has a significant impact on conflict incidence. However, the results do indicate a strong link between LSM production activities and local conflict. First, we find 
that the start of LSM production activities decreases battles between armed actors and increases riots. Specifically, when production concessions expand to cover an additional 10 percentage points of a cell's surface area, this entails a 0.26 percentage point decrease in the incidence of battles and a 0.12 percentage point increase in the incidence of riots. These findings are significant at the $1 \%$ and $5 \%$ significance level, respectively (see Columns 5 and 8 ). The average monthly incidence of these conflict events in cells with an LSM production concession equals $0.78 \%$ for battles and $0.31 \%$ for riots. The estimated coefficients thus imply a decrease of 33\% in the incidence of battles and an increase of $39 \%$ in the incidence of riots. These effects are sizable, considering that LSM production concessions on average cover $20 \%$ of a cell surface area when they are present. In section IV.B we discuss a range of sensitivity checks suggesting that the negative relationship between LSM production expansion and the incidence of battles is not driven by reverse causality.

Second, when the LSM activities expand into areas where artisanal miners are active, we find that both violence against civilians and looting increases. For every additional ASM site located within the boundaries of an expanding production concession, the incidence of violence against civilians and looting increases with 0.26 and 0.15 percentage points (see Columns 6 and 7). This implies an increase of $21 \%$ and $31 \%$ compared to the average monthly incidence of these events in cells where ASM is present. These effects are large, considering that the average production concession encompasses 7 ASM sites, with their number ranging between 1 and 48, for cells where ASM and LSM production activities coincide. We find no additional impact on battles and riots. 
In sum, these results indicate that the expansion of LSM production activities decreases battles between armed actors but increases the incidence of riots. Furthermore, when such expansion of LSM takes place in areas where artisanal mining is undertaken it leads to an increase in violence against civilians and looting. These results are in line with previously documented qualitative evidence about the impact of industrial mining.

To enter the production phase, LSM companies make considerable investments. As previously discussed, companies have clear incentives to safeguard these investments. To do so, they regularly receive the backing of the Congolese army and the Mining Police, while they can also rely on their own private security forces. As such, the company and its 'protectors' may outweigh other armed actors in terms of size and strength, thus creating a power asymmetry, making it less likely that they are challenged. This protection effect most likely underlies the documented decrease in battles. The documented increase in riots likely reflects the heightened discontent of local communities, who often have to relocate at the start of the LSM production phase. $^{29}$

That LSM's expansion into 'ASM sites' leads to more violence against civilians and looting is in line with anecdotal and case study evidence. Because artisanal mining activities are often halted when companies move to the production phase, the expansion constitutes a negative shock both to the income of artisanal miners and the armed actors taxing this income. In an

\footnotetext{
${ }^{29}$ Local communities may of course anticipate future changes associated with a move from the LSM research to the production phase and engage in riots before actual change has taken place. If riots are already on the rise during the research phase, this would attenuate our estimated impact of the start of the production phase.
} 
economy with few alternative economic opportunities, this may incentivize artisanal miners to join an armed group and to engage in acts of looting or violence. Geenen (2012, p. 327), for instance, has linked an unemployment shock in the artisanal mining sector to the "increased incidence of theft, robberies, armed attacks and murders". Similarly, armed actors that operate as stationary bandits and profit from taxing ASM activities may need to look for alternative sources of income, resorting to looting and other forms of violence against civilians (cfr. Parker and Vadheim, 2017). ${ }^{30}$

\section{Robustness}

Before we move to the conclusion, we show that our findings are robust across a range of checks. The analyses and results are presented in Appendix 4 and summarized here.

A first robustness check deals with spatial correlation. We test the robustness of the results to alternative specifications when calculating the standard errors. For each estimated coefficient, we present five sets of standard errors: clustering the standard errors at the level of the cell, and four sets of Conley standard errors with alternative spatial and temporal specifications. The results are robust across these alternative specifications (see Table A.7).

Conflicts may diffuse spatially. In a second check, we explore spatial spillovers in two ways. First, we follow an approach taken by Berman et al. (2017) and additionally control for the

\footnotetext{
30 An additional explanation may be that mining companies directly collaborate with armed groups to expand their extraction area, potentially entailing an increase in violence against civilians and looting (see e.g. Global Witness, 2016; Human Rights Watch, 2005). While plausible, this alternative explanation is perhaps more likely to hold for mining companies that have not been granted official mining permits, and hence do not receive armed support from the Mining Police or the Congolese army. As they are less well protected, one could assume that their incentives to secure an area of operation through other means increases (this reasoning is in line with the distinction that Berman et al. (2017) make regarding domestic versus foreign mining companies). Because our analysis relies on official LSM data from the Congolese Mining Cadaster, this alternative mechanism is less likely to drive the results than the one we put forward.
} 
number of neighboring cells that are in conflict. For all types of conflict events, we find that spatial spillovers from neighboring cells are positive and strongly significant, up to about twomonth time lags. The main results remain stable (see Table A.8). Second, we explore whether the expansion of LSM production activities also has an impact on conflict events in the wider geographical area surrounding mining concessions. We find that the protection effect of LSM also extends to $1^{\text {st }}$ degree neighboring cells. ${ }^{31}$ Specifically, an expansion in LSM production activities is associated with a decrease in the incidence of battles in neighboring cells without an LSM concession. We further note that an LSM production expansion has no significant impact on the incidence of riots in neighboring cells where LSM is not present or has not moved to the production phase; i.e. where local communities are less likely to be directly affected. However, when LSM production activities expand into areas already in use by artisanal miners, violence against civilians and looting also spills over to $1^{\text {st }}$ degree neighboring cells without LSM concessions. We also check whether these findings extend to $2^{\text {nd }}$ degree neighboring cells, but do not find any significant impact. Table A.9 presents the results.

A third set of robustness checks explores conflict intensity. First, we replace the monthly conflict dummies with variables that count the number of times the conflict events occurred in a specific cell and month. Second, we create two additional dependent variables: a dummy variable that indicates the monthly incidence of events with at least one fatality, and a variable

\footnotetext{
${ }^{31}$ Cells are approximately 25 x 25 kilometers. Hence, $1^{\text {st }}$ degree neighboring cells are located within a 25 -kilometer radius around cell i, while $2^{\text {nd }}$ degree neighboring cells are located within a 50-kilometer radius around cell i. Figure A.2 in Section B of Appendix 4 provides a visual representation.
} 
that counts the number of times such events occurred in a specific cell and month. The results, presented in Table A.10, are in line with the main results.

The fourth set of checks explores the robustness of our results to the definition of the value of mining sites. We first construct alternative measures of $\mathrm{ASM}_{\mathrm{i}} *$ price, $\mathrm{LSM}$ Research $\mathrm{it}_{\mathrm{it}}$ * price $_{\mathrm{t}}$ and LSM Production ${ }_{i t}{ }^{*}$ price $_{\mathrm{t}}$ using world mineral prices with a one-month and a six-month lag. These alternative specifications consider that conflict may not respond immediately to price changes. Moreover, they control for the fact that world mineral prices may be transmitted to local prices with some delay. The results are presented in Table A.11 and similar to the main findings. Second, we collapse our dataset to cell-year observations. The dependent variables now count the number of months during which conflict events occurred in cell $\mathrm{i}$ and year $\mathrm{t}$, while the other variables represent the yearly average of their baseline counterparts. The results are in line with the main results (see Table A.12).

Fifth, we make use of information provided by ACLED to distinguish between conflict events involving state and non-state armed actors. The Congolese army is mentioned as an actor in $44 \%$ of the conflict events in our database, including the large majority (81\%) of battle events, $25 \%$ of looting events and $9 \%$ of violence against civilians. The Congolese army plays a dual role. On the one hand, they provide security to industrial mining companies (e.g. Geenen, 2014, 2013; Kilosho Buraye et al., 2017). On the other hand, they are "the most important armed actors illegally benefitting from artisanal mining" (Weyns et al., 2016, p. 58). While the ACLED database does not allow us to tease out this dual role in detail, we can separately 
estimate equation (3) for conflict events with and without the involvement of state armed actors. The results are presented in Table A.13 and are in line with the main findings.

Finally, following a number of recent papers (Maystadt et al. 2014; Miguel et al. 2004; Parker and Vadheim 2017), we control for rainfall to capture exogenous shocks to agricultural income. On the one hand, an increase in agricultural income may raise the opportunity cost to join armed groups; on the other hand, it may increase armed groups' incentives to loot communities. Heavy rainfall could also hinder mining activities and the movement of armed groups. We use monthly rainfall data from the Climatic Research Unit of the University of East Anglia to calculate contemporaneous and lagged rainfall anomalies (that measure the monthly deviation from the long-term monthly mean) and to construct indicators for cell-specific dry and wet seasons. Details are provided in Section F of Appendix 4. The results again confirm our main findings (see Table A.14).

\section{Conclusion}

This paper studies the impact of artisanal and industrial mining, including their interaction, on local conflict. Previous studies have found a link between mining and local conflict but did not distinguish between the mode of mineral extraction (Berman et al., 2017). Doing so, however, is important. Artisanal and industrial mining are often clustered in space but may have distinct and sometimes opposite effects on the level and type of violence. First, we find that an exogenous rise in the value of ASM sites leads to increases in battles, attacks against civilians and looting, indicating competition between rapacious armed groups. In contrast, a change in 
the value of LSM sites has little to no effect on conflict. Second, we find that battles decrease when LSM moves to the production phase. This is consistent with the idea that large, industrial mining companies have the means and incentives to establish a monopoly of power and secure their concessions. A move to the LSM production phase also increases the incidence of riots, reflecting actions by local communities who are negatively affected. Finally, in cases where industrial production activities expand into areas that are already in use by artisanal miners, we find an increase in attacks against civilians and looting. Individuals who previously profited from ASM, whether they are armed actors or artisanal miners, turn to alternative sources of finance like looting and attacking civilians.

The geographic focus of our analysis - Eastern Congo - is dictated by the unique availability of a large-scale geo-referenced database on artisanal mining sites. It is worth noting, however, that the environment of our study is similar to that found in many developing countries on some key dimensions. First, in many other mining areas in the developing world, both modes of mineral extraction are present and spatially clustered, and their relationship tends to be troubled by conflict (World Bank, 2009, 2010). Second, many ASM and LSM activities in Africa take place in a context of state weakness. Third, in part due to their fiscal revenue-generating potential, large-scaling mining companies tend to be backed by the government. While it is likely that the impact of ASM, LSM and their interaction on local conflict differs across countries and from context to context (see e.g. Berman et al., 2017), our findings with regard to the expansion of LSM production activities are in line with ample qualitative case-study evidence from a wide range of African contexts. 
In terms of policy, our results highlight the need to assess mining policies through a political economy lens. Governments and policy-prescribers like the IMF and the World Bank tend to favor industrial mining over artisanal mining because of its fiscal revenue-generating potential. While the relation between mineral price increases and local conflict at ASM sites - and its relative absence at LSM sites - may add to the arguments of those who seek to replace ASM by LSM, there are two important considerations.

First, a major difference between ASM and LSM sites is that mining companies, being backed by the government and national army, are able to secure their concessions. There is, however, nothing inherent about ASM sites that prevents the same type of security. Second, our results emphasize the need to think carefully about the costs of expanding LSM. Worldwide, the livelihoods of more than 100 million people depend on ASM, with up to 20 million living in Africa (World Bank, 2009, p. 9). Recent evidence looking at the economic impact of mining further shows that while ASM significantly contributes to household consumption, the opening of industrial mines does not (Bazillier and Girard, 2019). Any policy to expand LSM should therefore incorporate measures that protect local mining communities and mitigate unintended economic and political effects, including the effect on the behavior of armed actors. 


\section{REFERENCES}

Acemoglu, D., Robinson, J.A., 2013. Economics versus Politics: Pitfalls of Policy Advice. J. Econ. Perspect. 27, 173-192.

African Economic Outlook, 2014. Congo, Democratic Republic. African Economic Outlook.

Angrist, J.D., Kugler, A.D., 2008. Rural Windfall or a New Resource Curse? Coca, Income, and Civil Conflict in Colombia. Rev. Econ. Stat. 90, 191-215.

Autesserre, S., 2010. The Trouble with the Congo. Local Violence and the Failure of International Peacebuilding. Cambridge University Press, Cambridge.

Banchirigah, S.M., 2008. Challenges with Eradicating Illegal Mining in Ghana: A Perspective from the Grassroots. Resour. Policy 33, 29-38.

Bazillier, R., Girard, V., 2019. The Gold Digger and the Machine Evidence on the Distributive Effect of the Artisanal and Industrial Gold Rushes in Burkina Faso. NOVAFRICA Work. Pap. Ser. 47.

Bazzi, S., Blattman, C., 2014. Economic Shocks and Conflict: Evidence from Commodity Prices. Am. Econ. J. Macroecon. 6, 1-38.

Becker, G.S., 1968. Crime and Punishment: An Economic Approach. J. Polit. Econ. 76, 169217.

Berman, N., Couttenier, M., Rohner, D., Thoenig, M., 2017. This Mine Is Mine! How Minerals Fuel Conflicts in Africa. Am. Econ. Rev. 107, 1564-1610.

Besley, T., Reynal-Querol, M., 2014. The Legacy of Historical Conflict: Evidence from Africa. Am. Polit. Sci. Rev. 108, 319-336.

Blattman, C., Miguel, E., 2010. Civil War. J. Econ. Lit. 48, 3-57.

Bush, R., 2009. 'Soon There Will Be No-One Left to Take the Corpses to the Morgue': Accumulation and Abjection in Ghana's Mining Communities. Resour. Policy, SmallScale Mining, Poverty and Development in Sub-Saharan Africa 34, 57-63.

Campbell, B. (Ed.), 2009. Mining in Africa: Regulation and Development. Pluto Press, New York.

Canuto, O., 2014. The Commodity Super Cycle: Is This Time Different? The World Bank.

Carstens, J., Hilson, G., 2009. Mining, Grievance and Conflict in Rural Tanzania. Int. Dev. Plan. Rev. 31, 301-326.

Collier, P., Hoeffler, A., 2004. Greed and Grievance in Civil War. Oxf. Econ. Pap. 56, 563595.

Collier, P., Hoeffler, A., 1998. On Economic Causes of Civil War. Oxf. Econ. Pap. 50, 563573.

Conley, T.G., 1999. GMM Estimation with Cross Sectional Dependence. J. Econom. 92, 1-45.

Cotet, A.M., Tsui, K.K., 2013. Oil and Conflict: What Does the Cross Country Evidence Really Show? Am. Econ. J. Macroecon. 5, 49-80.

Dal Bó, E., Dal Bó, P., 2011. Workers, Warriors, and Criminals: Social Conflict in General Equilibrium. J. Eur. Econ. Assoc. 9, 646-677. 
Dube, O., Vargas, J.F., 2013. Commodity Price Shocks and Civil Conflict: Evidence from Colombia. Rev. Econ. Stud. 80, 1384-1421.

EITI, 2014. Generating "Ripple Effects" in DR Congo. Extr. Ind. Transpar. Initiat. URL http://eiti.org/news/generating-ripple-effects-dr-congo.

Fearon, J.D., 2005. Primary Commodity Exports and Civil War. J. Confl. Resolut. 49, 483507.

Fearon, J.D., 1995. Rationalist Explanations for War. Int. Organ. 49, 379-414.

Fearon, J.D., Laitin, D.D., 2003. Ethnicity, Insurgency, and Civil War. Am. Polit. Sci. Rev. 97, 75-90.

Geenen, S., 2014. "Qui Cherche, Trouve" the Political Economy of Access to Gold Mining and Trade in South Kivu, DRC.

Geenen, S., 2013. Dispossession, Displacement and Resistance: Artisanal Miners in a Gold Concession in South-Kivu, Democratic Republic of Congo. Resour. Policy.

Geenen, S., 2012. A Dangerous Bet: The Challenges of Formalizing Artisanal Mining in DRC. Resour. Policy 37, 322-330.

Global Witness, 2016. River of gold. How the state lost out in an Eastern Congo gold boom, while armed groups, a foreign mining company and provincial authorities pocketed millions. Global Witness, London.

Grossman, H.I., 1999. Kleptocracy and Revolutions. Oxf. Econ. Pap. 51, 267-283.

Grossman, H.I., 1991. A General Equilibrium Model of Insurrections. Am. Econ. Rev. 81, 912921.

Hilson, G., Yakovleva, N., 2007. Strained relations: A critical analysis of the mining conflict in Prestea, Ghana. Polit. Geogr. 26, 98-119.

Hirshleifer, J., 1991. The Technology of Conflict as an Economic Activity. Am. Econ. Rev. 81, 130-134.

Hsiang, S.M., Meng, K.C., Cane, M.A., 2011. Civil Conflicts Are Associated with the Global Climate. Nature 476, 438.

Human Rights Watch, 2005. The Curse of Gold. Democratic Republic of Congo. Human Rights Watch, New York.

Humphreys, D., 2010. The Great Metals Boom: A Retrospective. Resour. Policy 35, 1-13.

Humphreys, M., 2005. Natural Resources, Conflict, and Conflict Resolution Uncovering the Mechanisms. J. Confl. Resolut. 49, 508-537.

IRC, 2007. Mortality in the Democratic Republic of Congo: An Ongoing Crisis.

Kilosho Buraye, J., Stoop, N., Verpoorten, M., 2017. Defusing the social minefield of gold sites in Kamituga, South Kivu. From legal pluralism to the re-making of institutions? Resour. Policy 53, 356-368.

Laudati, A., 2013. Beyond Minerals: Broadening 'Economies of Violence' in Eastern Democratic Republic of Congo. Rev. Afr. Polit. Econ. 40, 32-50.

Lei, Y.-H., Michaels, G., 2014. Do Giant Oilfield Discoveries Fuel Internal Armed Conflicts? J. Dev. Econ. 110, 139-157. 
Lujala, P., 2010. The Spoils of Nature: Armed Civil Conflict and Rebel Access to Natural Resources. J. Peace Res. 47, 15-28.

Maystadt, J.-F., De Luca, G., Sekeris, P.G., Ulimwengu, J., 2014. Mineral Resources and Conflicts in DRC: A Case of Ecological Fallacy? Oxf. Econ. Pap. 66, 721-749.

Maystadt, J.-F., Ecker, O., 2014. Extreme Weather and Civil War: Does Drought Fuel Conflict in Somalia through Livestock Price Shocks? Am. J. Agric. Econ. 96, 1157-1182.

Mazalto, M., 2005. La Réforme Des Législations Minières En Afrique Et Le Rôle Des Institutions Financières Internationales: La République Démocratique Du Congo, in: Marysse, S., Reyntjens, F. (Eds.), L'Afrique Des Grands Lacs Annuaire 2004-2005. L'Harmattan, Paris, pp. 263-287.

Michalopoulos, S., Papaioannou, E., 2016. The Long-Run Effects of the Scramble for Africa. Am. Econ. Rev. 106, 1802-1848.

Miguel, E., Satyanath, S., Sergenti, E., 2004. Economic Shocks and Civil Conflict: An Instrumental Variables Approach. J. Polit. Econ. 112, 725-753.

Minoiu, C., Shemyakina, O.N., 2014. Armed Conflict, Household Victimization, and Child Health in Côte d'Ivoire. J. Dev. Econ. 108, 237-255.

Olson, M., 1993. Dictatorship, Democracy, and Development. Am. Polit. Sci. Rev. 87, 567576.

Olsson, O., 2007. Conflict diamonds. J. Dev. Econ. 82, 267-286.

Parker, D.P., Vadheim, B., 2017. Resource Cursed or Policy Cursed? US Regulation of Conflict Minerals and Violence in the Congo. J. Assoc. Environ. Resour. Econ. 4, 1-49.

Raleigh, C., Dowd, C., 2016. Armed Conflict Location and Event Data Project (ACLED) Codebook 2016. ACLED.

Raleigh, C., Linke, A., Hegre, H., Karlsen, J., 2010. Introducing Acled. J. Peace Res. 47, 651660.

Reyntjens, F., 2010. The Great African War: Congo and Regional Geopolitics, 1996 - 2006. Cambridge Univ. Press, Cambridge.

Ross, M., 2006. A Closer Look at Oil, Diamonds, and Civil War. Annu. Rev. Polit. Sci. 9, 265300.

Ross, M., 2004. What Do We Know About Natural Resources and Civil War? J. Peace Res. 41, 337-356.

Ross, M., 2003. Oil, Drugs, and Diamonds: The Varying Role of Natural Resources in Civil War, in: Ballentine, K., Sherman, J. (Eds.), The Political Economy of Armed Conflict: Beyond Greed and Grievance. Lynne Rienner, Boulder, CO, pp. 47-70.

Sanchez de la Sierra, R., 2019. On the Origins of the State: Stationary Bandits and Taxation in Eastern Congo. J. Polit. Econ.

Schouten, P., Murairi, J., Kubuya, S., 2017. "Everything That Moves Will Be Taxed": The Political Economy of Roadblocks in North and South Kivu. International Peace Information Service. 
Seay, L., 2012. What's Wrong with Dodd-Frank 1502? Conflict Minerals, Civilian Livelihoods, and the Unintended Consequences of Western Advocacy (No. 284), Working Paper. Center for Global Development.

Stearns, J., 2013a. Banyamulenge: Insurgency and Exclusion in the Mountains of South Kivu, Usalama Project. Rift Valley Institute, London.

Stearns, J., 2013b. Raia Mutomboki. the Flawed Peace Process in the DRC and the Birth of an Armed Franchise, Usalama Project. Rift Valley Institute.

Stearns, J., 2011. Dancing in the Glory of Monsters: The Collapse of the Congo and the Great War. Public Affairs, New York.

Stearns, J., Vogel, C., 2015. The Landscape of Armed Groups in the Eastern Congo. Congo Res. Group Cent. Int. Coop.

Stoop, N., Verpoorten, M., Van der Windt, P., 2018. More legislation, more violence? The impact of Dodd-Frank in the DRC. PLOS ONE 13, e0201783.

Sundberg, R., Melander, E., 2013. Introducing the UCDP Georeferenced Event Dataset. J. Peace Res. 50, 523-532.

UNEP, 2011. Post-Conflict Environmental Assessment of the Democratic Republic of Congo: Synthesis Report for Policy Makers. United Nations Environment Programme, Nairobi, Kenya.

USGS, 2015. Mineral Commodity Summaries, 2015. United States Geological Survey.

USGS, 2013. Mineral Commodity Summaries, 2013. United States Geological Survey.

Van der Ploeg, F., 2011. Natural Resources: Curse or Blessing? J. Econ. Lit. 49, 366-420.

van Puijenbroeck, J., Schouten, P., 2013. Le 6ième Chantier? L'économie Politique de L'exploitation Auifière Artisanale et le Sous-Développement en Ituri. Afr. Gd. Lacs Annu. 2012-2013.

Vlassenroot, K., 2013. South Kivu. Identity, Territory, and Power in the Eastern Congo, Usalama Project. Rift Valley Institute.

Vogel, C., Mvano, C., 2016. The Dogged Persistance of the FDLR. Congo Res. Group. URL http://congoresearchgroup.org/guest-blog-the-dogged-persistence-of-the-fdlr/.

Weyns, Y., Hoex, L., Matthysen, K., 2016. Analysis of the Interactive Map of Artisanal Mining Areas in Eastern DR Congo. 2015 Update. IPIS, Antwerp.

World Bank, 2016. World Development Indicators. World DataBank. URL http://databank.worldbank.org.

World Bank, 2010. Working Together. How large-scale mining can engage with artisanal and small-scale miners. International Finance Corporation (IFC), Communities and SmallScale Mining (CASM), International Council on Mining \& Metals (ICMM).

World Bank, 2009. Mining Together. Large-Scale Mining meets Artisanal Mining: A Guide for Action. Communities and Small-scale Mining.

World Bank, 2008. Democratic Republic of Congo - Growth with Governance in the Mining Sector (No. 43402- ZR). World Bank. 


\section{FIGURES}
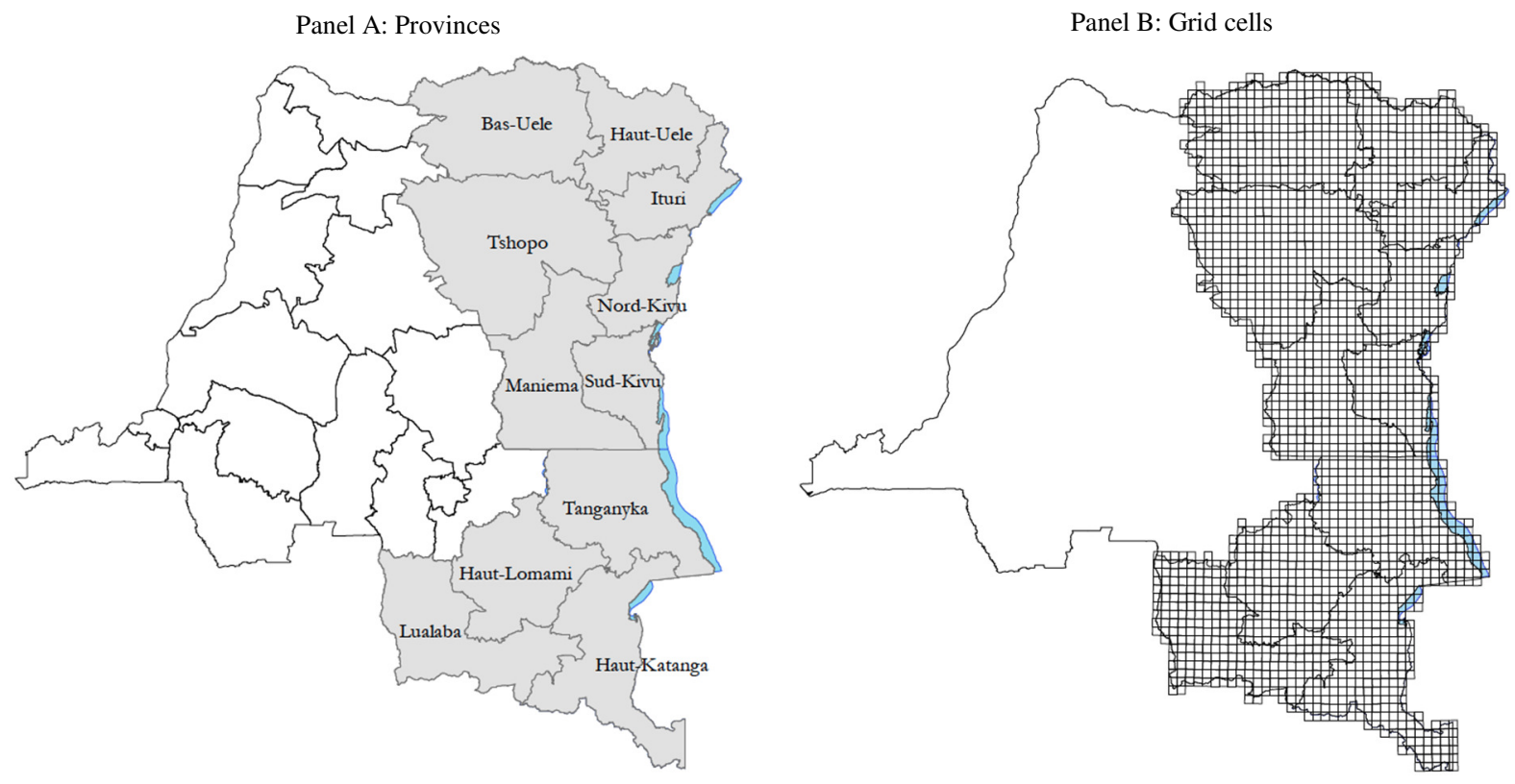

FIGURE 1. EASTERN CONGO

Notes: Panel A shows the 26 provinces of the DRC. The shaded area covers the eleven eastern provinces which encompass the former province of Orientale (now: Bas-Uele, Haut-Uele, Tshopo and Ituri), North-Kivu, South-Kivu, Maniema and the former province of Katanga (now: Tanganyka, Haut-Lomami, Lualaba and Haut-Katanga). Panel B shows the 2,176 grid cells of $625 \mathrm{~km}^{2}$ that we take as our units of analysis. 
Panel A: World Prices of Gold, 3T Minerals and copper
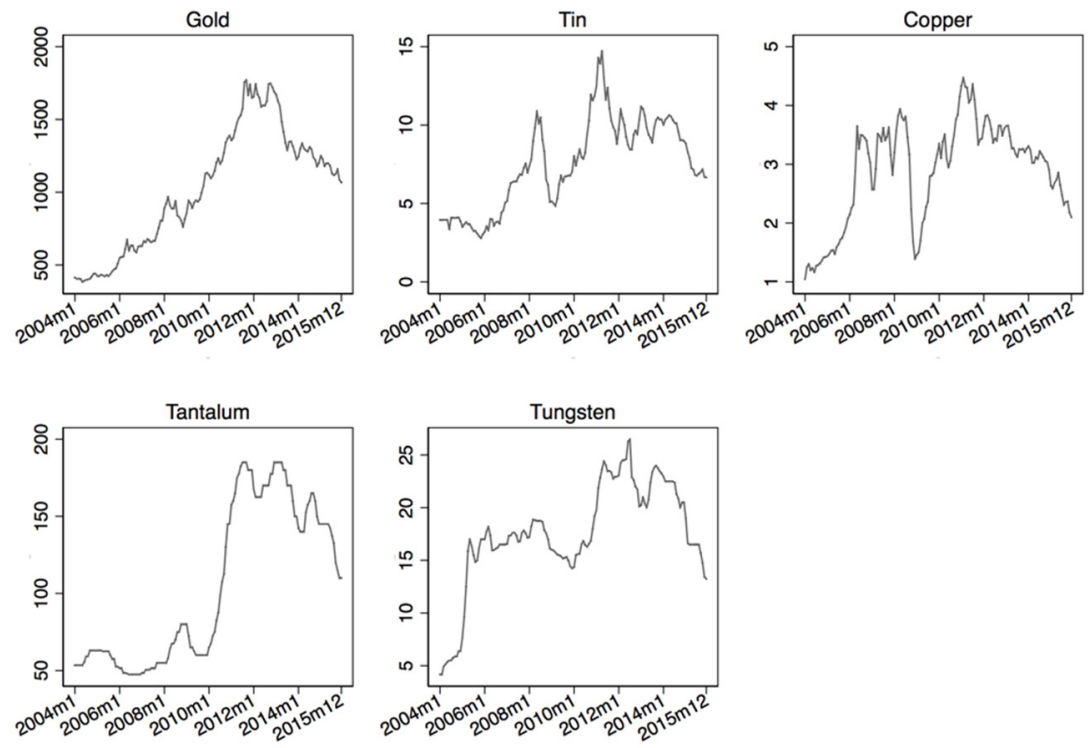

Panel B: Expansion of Industrial Mining
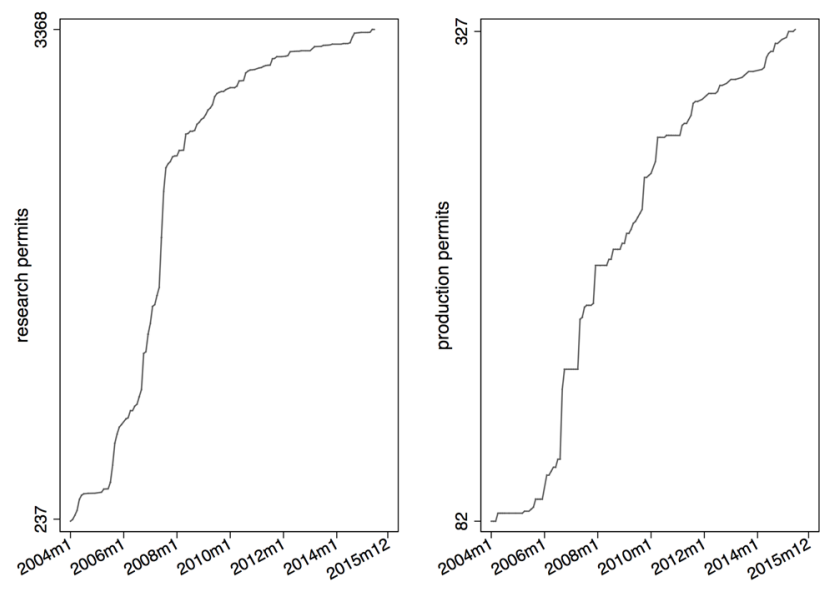

Figure 2. SOURCES OF VARIATION IN THE CONGOLESE Mining SECTOR

Notes: Panel A shows the monthly averages of world prices for gold, tin, tantalum and tungsten for the period 2004-2015 in 2015 US dollars. Gold prices are reported in US dollars per troy ounce. 3T and copper prices are reported in US dollars per pound. Panel B shows the total number of granted research and production permits in Eastern Congo. The data on mineral prices were obtained from metalprices.com; the data on industrial mining come from the CAMI database (see Section III). 
Panel A: Battles and Violence (ACLED)

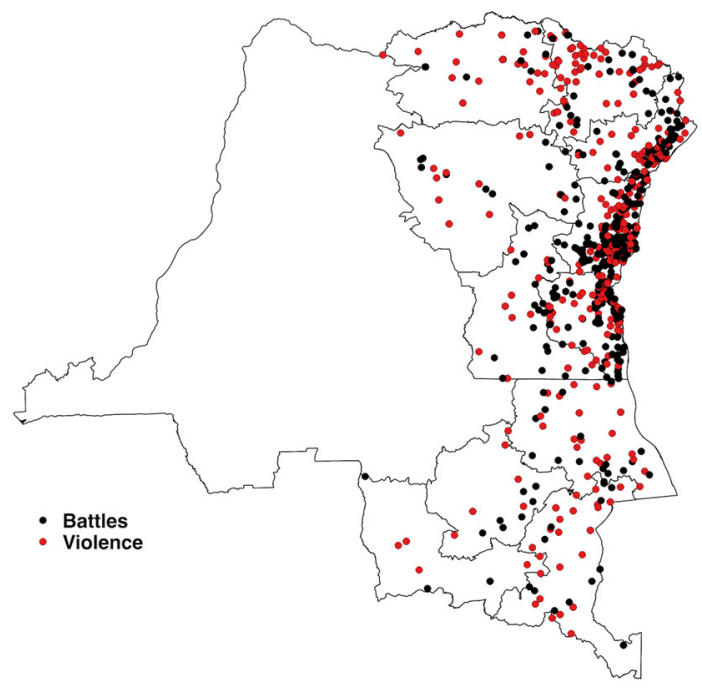

Panel C: Artisanal mining sites (IPIS)

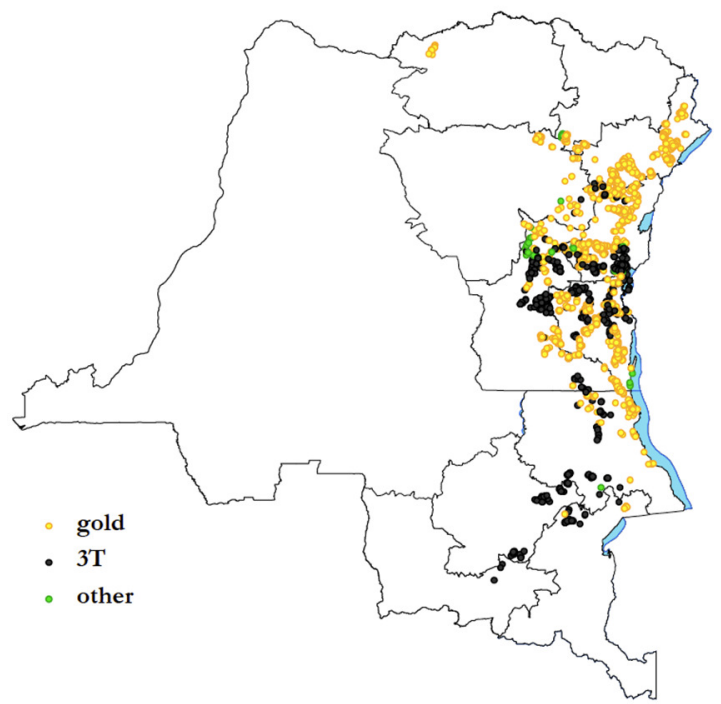

Panel B: Riots and Looting (ACLED)

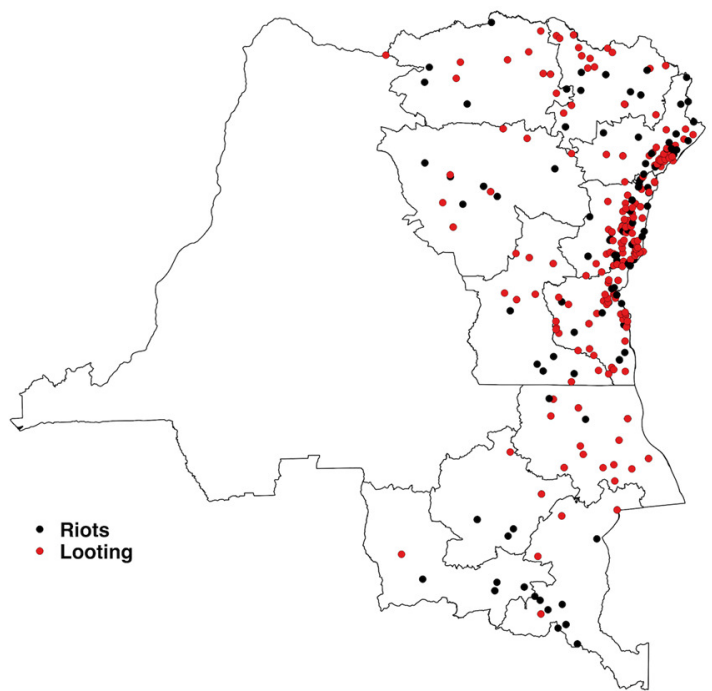

Panel D: Mining concessions (CAMI)

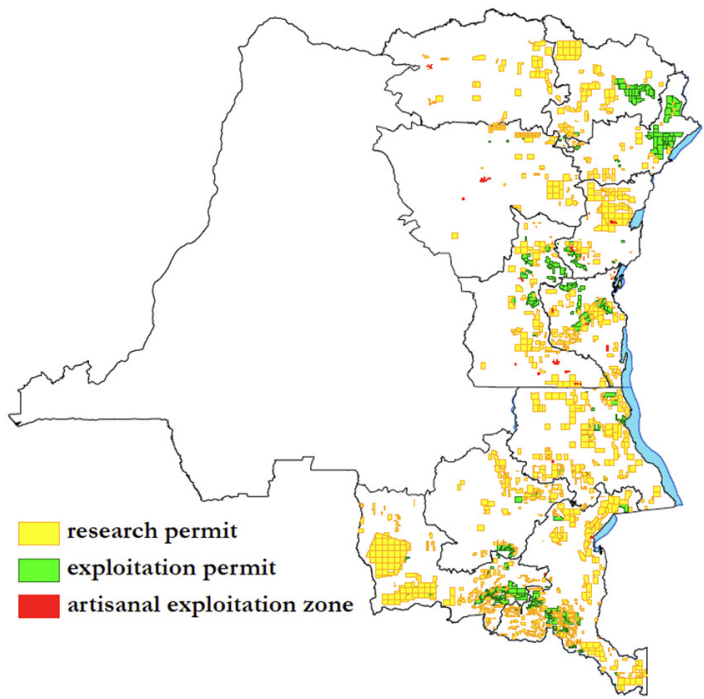

FIGURE 3. LOCATION OF CONFLICT EVENTS, ASM SITES AND LSM CONCESSIONS

Notes: Panel A and B show the location of ACLED conflict events that occurred between 2004-2015. Panel C shows the location of artisanal mining sites in the most recent database of IPIS. Panel D shows the location of the large-scale mining concessions in the CAMI database that were covered by a valid permit at the end of 2015. 

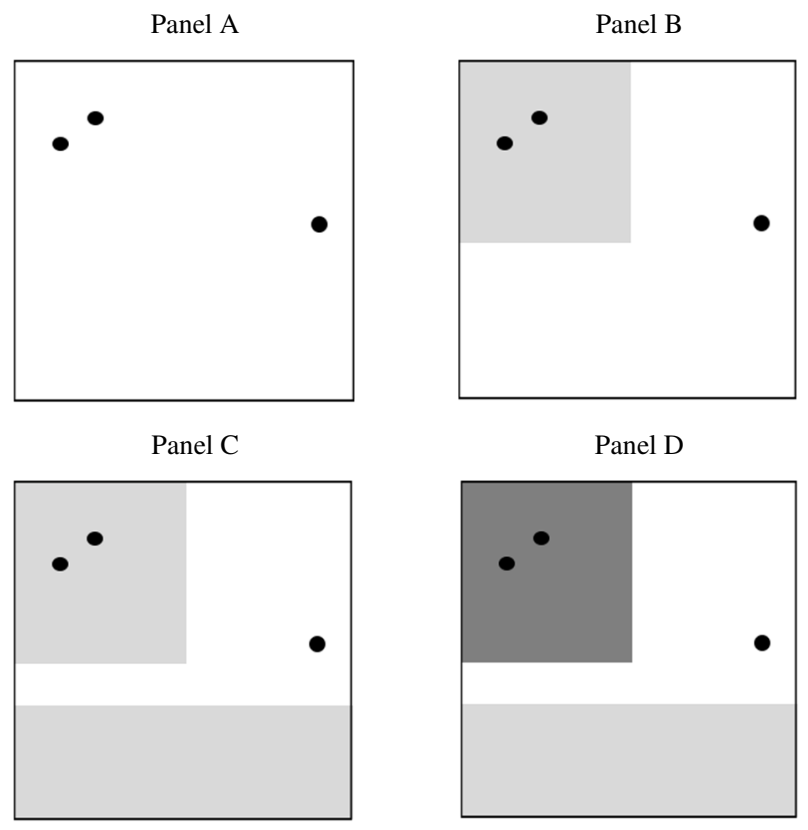

FigURE 4. EXPANSION OF LARGE-SCALE MINING IN A CELL

Notes: Light grey areas indicate concessions covered by an LSM research permit, dark grey areas indicate concessions covered by an LSM production permit, and black dots denote the location of ASM sites. 


\section{TABLES}

TABLE 1-SUMMARY STATISTICS

\begin{tabular}{|c|c|c|c|c|c|}
\hline incidence of battles & 2,176 & 0.13 & 0.34 & 0 & 1 \\
\hline incidence of violence & 2,176 & 0.14 & 0.35 & 0 & 1 \\
\hline incidence of looting & 2,176 & 0.07 & 0.26 & 0 & 1 \\
\hline \# of months with battle & 2,176 & 0.66 & 3.77 & 0 & 68 \\
\hline \# of months with looting & 2,176 & 0.23 & 1.46 & 0 & 26 \\
\hline monthly incidence of battles & 313,344 & 0.005 & 0.067 & 0 & 1 \\
\hline monthly incidence of violence & 313,344 & 0.005 & 0.068 & 0 & 1 \\
\hline monthly incidence of riots & 313,344 & 0.001 & 0.035 & 0 & 1 \\
\hline monthly incidence of looting & 313,344 & 0.002 & 0.040 & 0 & 1 \\
\hline \# ASM gold sites & 2,176 & 0.64 & 3.09 & 0 & 50 \\
\hline \# ASM 3T sites & 2,176 & 0.27 & 1.60 & 0 & 30 \\
\hline share LSM research concessions & 313,344 & 0.28 & 0.32 & 0 & 1 \\
\hline share LSM production concessions & 313,344 & 0.02 & 0.09 & 0 & 1 \\
\hline
\end{tabular}

Notes: This Table shows summary statistics at the level of the grid cell. Information on conflict events was calculated from the ACLED database; information on ASM sites was calculated from the IPIS database; information on LSM concessions was calculated from the CAMI database. 
TABLE 2-MINERAL PRICES AND CONFLICT

\begin{tabular}{|c|c|c|c|c|}
\hline \multirow{2}{*}{$\begin{array}{l}\text { Sample } \\
\text { Dependent variable }\end{array}$} & \multicolumn{2}{|c|}{ No change LSM } & \multicolumn{2}{|c|}{ Ever LSM 2004-2015 } \\
\hline & $\begin{array}{c}\text { Battles } \\
(1)\end{array}$ & $\begin{array}{l}\text { Violence } \\
\text { (2) }\end{array}$ & $\begin{array}{l}\text { Battles } \\
\text { (3) }\end{array}$ & $\begin{array}{l}\text { Violence } \\
\text { (4) }\end{array}$ \\
\hline $\begin{array}{l}\text { Panel A: LSM mines } \\
\text { LSM * price }\end{array}$ & $\begin{array}{l}0.0015^{*} \\
(0.0008)\end{array}$ & $\begin{array}{c}0.0005 \\
(0.0008)\end{array}$ & $\begin{array}{c}0.0011 * * \\
(0.0004)\end{array}$ & $\begin{array}{c}0.0012 * * * \\
(0.0004)\end{array}$ \\
\hline $\begin{array}{l}\text { Panel B: LSM and ASM mines } \\
\text { LSM * price }\end{array}$ & $\begin{array}{c}0.0008 \\
(0.0007)\end{array}$ & $\begin{array}{l}-0.0000 \\
(0.0006)\end{array}$ & $\begin{array}{l}0.0006^{*} \\
(0.0004)\end{array}$ & $\begin{array}{l}0.0007 * \\
(0.0004)\end{array}$ \\
\hline ASM * price & $\begin{array}{c}0.0044 * * \\
(0.0019)\end{array}$ & $\begin{array}{l}0.0031^{*} \\
(0.0017)\end{array}$ & $\begin{array}{c}0.0040 * * * \\
(0.0013)\end{array}$ & $\begin{array}{c}0.0040 * * * \\
(0.0012)\end{array}$ \\
\hline $\begin{array}{l}F \text {-test: } L S M * \text { price }=A S M * \text { price } \\
p \text {-value of } F \text {-test }\end{array}$ & $\begin{array}{c}3.66 \\
(0.056)\end{array}$ & $\begin{array}{c}3.77 \\
(0.052)\end{array}$ & $\begin{array}{l}7.41 \\
(0.007)\end{array}$ & $\begin{array}{c}8.51 \\
(0.004)\end{array}$ \\
\hline $\begin{array}{l}\text { Observations } \\
\text { Cell FE } \\
\text { Month FE }\end{array}$ & $\begin{array}{c}127,872 \\
\text { Yes } \\
\text { Yes }\end{array}$ & $\begin{array}{c}127,872 \\
\text { Yes } \\
\text { Yes }\end{array}$ & $\begin{array}{c}313,344 \\
\text { Yes } \\
\text { Yes }\end{array}$ & $\begin{array}{c}313,344 \\
\text { Yes } \\
\text { Yes }\end{array}$ \\
\hline
\end{tabular}

Notes: $* * * \mathrm{p}<0.01,{ }^{* *} \mathrm{p}<0.05,{ }^{*} \mathrm{p}<0.1$; LPM estimations; Conley (1999) standard errors in parentheses, allowing for spatial correlation within a $500 \mathrm{~km}$. radius and infinite serial correlation. 
TABLE 3-EXPANSION OF LARGE-SCALE MINING AND CONFLICT

\begin{tabular}{|c|c|c|c|c|c|c|c|c|}
\hline & \multicolumn{4}{|c|}{ Panel A } & \multicolumn{4}{|c|}{ Panel B } \\
\hline & $\begin{array}{l}\text { Battles } \\
\text { (1) }\end{array}$ & $\begin{array}{c}\text { Violence } \\
\text { (2) }\end{array}$ & $\begin{array}{l}\text { Looting } \\
\text { (3) }\end{array}$ & $\begin{array}{l}\text { Riots } \\
(4)\end{array}$ & $\begin{array}{c}\text { Battles } \\
(5)\end{array}$ & $\begin{array}{c}\text { Violence } \\
(6)\end{array}$ & $\begin{array}{c}\text { Looting } \\
(7)\end{array}$ & $\begin{array}{l}\text { Riots } \\
(8)\end{array}$ \\
\hline $\mathrm{ASM} *$ price & $\begin{array}{c}0.0043 * * * \\
(0.0014)\end{array}$ & $\begin{array}{c}0.0042 * * \\
(0.0012)\end{array}$ & $\begin{array}{c}0.0020 * * \\
(0.0007)\end{array}$ & $\begin{array}{c}0.0007 \\
(0.0005)\end{array}$ & $\begin{array}{c}0.0040 * * \\
(0.0016)\end{array}$ & $\begin{array}{c}0.0037 \text { *** } \\
(0.0013)\end{array}$ & $\begin{array}{c}0.0017 * * \\
(0.0008)\end{array}$ & $\begin{array}{c}0.0007 \\
(0.0005)\end{array}$ \\
\hline LSM research $*$ price & $\begin{array}{c}0.0017 \\
(0.0012)\end{array}$ & $\begin{array}{c}0.0010 \\
(0.0011)\end{array}$ & $\begin{array}{c}0.0006 \\
(0.0005)\end{array}$ & $\begin{array}{c}-0.0003 \\
(0.0002)\end{array}$ & $\begin{array}{c}0.0017 \\
(0.0012)\end{array}$ & $\begin{array}{c}0.0011 \\
(0.0011)\end{array}$ & $\begin{array}{c}0.0006 \\
(0.0005)\end{array}$ & $\begin{array}{c}-0.0003 \\
(0.0002)\end{array}$ \\
\hline LSM production * price & $\begin{array}{c}0.0028 \\
(0.0040)\end{array}$ & $\begin{array}{l}-0.0049 \\
(0.0041)\end{array}$ & $\begin{array}{c}0.0038 \\
(0.0033)\end{array}$ & $\begin{array}{c}0.0026 \\
(0.0031)\end{array}$ & $\begin{array}{c}0.0031 \\
(0.0040)\end{array}$ & $\begin{array}{l}-0.0059 \\
(0.0041)\end{array}$ & $\begin{array}{c}0.0033 \\
(0.0030)\end{array}$ & $\begin{array}{c}0.0023 \\
(0.0028)\end{array}$ \\
\hline LSM research & $\begin{array}{l}-0.0000 \\
(0.0011)\end{array}$ & $\begin{array}{c}0.0000 \\
(0.0010)\end{array}$ & $\begin{array}{c}0.0001 \\
(0.0005)\end{array}$ & $\begin{array}{l}-0.0003 \\
(0.0004)\end{array}$ & $\begin{array}{l}-0.0002 \\
(0.0011)\end{array}$ & $\begin{array}{l}-0.0000 \\
(0.0010)\end{array}$ & $\begin{array}{c}0.0001 \\
(0.0005)\end{array}$ & $\begin{array}{c}-0.0002 \\
(0.0004)\end{array}$ \\
\hline LSM production & $\begin{array}{c}-0.0272 * * * * \\
(0.0098)\end{array}$ & $\begin{array}{l}0.0121 * \\
(0.0066)\end{array}$ & $\begin{array}{c}0.0071 \\
(0.0063)\end{array}$ & $\begin{array}{c}0.0142 * * \\
(0.0066)\end{array}$ & $\begin{array}{c}-0.0263 * * * * \\
(0.0086)\end{array}$ & $\begin{array}{c}0.0026 \\
(0.0051)\end{array}$ & $\begin{array}{c}0.0015 \\
(0.0041)\end{array}$ & $\begin{array}{c}0.0120 * * \\
(0.0056)\end{array}$ \\
\hline LSM research in ASM & & & & & $\begin{array}{c}0.0003 \\
(0.0004)\end{array}$ & $\begin{array}{l}-0.0000 \\
(0.0003)\end{array}$ & $\begin{array}{c}0.0000 \\
(0.0002)\end{array}$ & $\begin{array}{c}-0.0001 \\
(0.0001)\end{array}$ \\
\hline LSM production in ASM & & & & & $\begin{array}{c}-0.0002 \\
(0.0010) \\
\end{array}$ & $\begin{array}{c}0.0026^{* * * *} \\
(0.0010) \\
\end{array}$ & $\begin{array}{l}0.0015^{*} \\
(0.0009) \\
\end{array}$ & $\begin{array}{c}0.0006 \\
(0.0008) \\
\end{array}$ \\
\hline Observations & 313,344 & 313,344 & 313,344 & 313,344 & 313,344 & 313,344 & 313,344 & 313,344 \\
\hline Cell FE & Yes & Yes & Yes & Yes & Yes & Yes & Yes & Yes \\
\hline Month FE & Yes & Yes & Yes & Yes & Yes & Yes & Yes & Yes \\
\hline
\end{tabular}

Notes: *** $\mathrm{p}<0.01, * * \mathrm{p}<0.05, * \mathrm{p}<0.1$; LPM estimations; Conley (1999) standard errors in parentheses, allowing for spatial correlation within a $500 \mathrm{~km}$. radius and infinite serial correlation; Panel A and B present results from the estimation of equations (2) and (3) respectively. 


\section{Appendix 1: Excluding Tantalum}

The assumption that world mineral prices are not affected by local conflict events in Eastern Congo may not hold for tantalum, since the DRC's share of total world production for tantalum fluctuates between 10-20\% (USGS 2013, 2015). Cells dominated by tantalum mining represent about $6 \%$ of cells with ASM sites and about $0.6 \%$ of cells with LSM concessions. The results in Table A.1 indicate that our baseline findings remain stable when dropping these cells from the analysis.

TABLE A.1-EXCLUDING TANTALUM

\begin{tabular}{lcccc}
\hline \hline & Battles & Violence & Looting & $(3)$ \\
& $(1)$ & $(2)$ & $\begin{array}{c}\text { Riots } \\
(4)\end{array}$ \\
\hline ASM * price & $0.0036^{* *}$ & $0.0037^{* * *}$ & $0.0018^{* *}$ & 0.0005 \\
& $(0.0016)$ & $(0.0013)$ & $(0.0008)$ & $(0.0005)$ \\
LSM research * price & 0.0016 & 0.0011 & 0.0006 & $-0.0003^{*}$ \\
& $(0.0012)$ & $(0.0011)$ & $(0.0005)$ & $(0.0002)$ \\
LSM production * price & 0.0029 & -0.0057 & 0.0034 & 0.0020 \\
& $(0.0041)$ & $(0.0042)$ & $(0.0031)$ & $(0.0028)$ \\
LSM research & -0.0003 & -0.0002 & -0.0001 & -0.0003 \\
& $(0.0010)$ & $(0.0010)$ & $(0.0004)$ & $(0.0004)$ \\
LSM production & $-0.0253^{* * *}$ & 0.0025 & 0.0011 & $0.0124 * *$ \\
& $(0.0086)$ & $(0.0051)$ & $(0.0041)$ & $(0.0056)$ \\
LSM research in ASM & 0.0004 & -0.0000 & -0.0000 & -0.0001 \\
& $(0.0004)$ & $(0.0003)$ & $(0.0002)$ & $(0.0001)$ \\
LSM production in ASM & -0.0002 & $0.0027 * * *$ & $0.0016 *$ & 0.0006 \\
& $(0.0011)$ & $(0.0010)$ & $(0.0009)$ & $(0.0009)$ \\
\hline Observations & 309,312 & 309,312 & 309,312 & 309,312 \\
Cell FE & Yes & Yes & Yes & Yes \\
Month FE & Yes & Yes & Yes & Yes \\
\hline
\end{tabular}

Notes: $* * * \mathrm{p}<0.01, * * \mathrm{p}<0.05, * \mathrm{p}<0.1$; LPM estimations; Conley (1999) standard errors in parentheses, allowing for spatial correlation within a $500 \mathrm{~km}$. radius and infinite serial correlation; Cells in which tantalum is the dominant ASM or LSM mineral are now dropped. 


\section{Appendix 2: Dodd-Frank}

The Dodd-Frank period may provide a notable exception to the transmission from international to local mineral prices. In July 2010, section 1502 of the Dodd-Frank Act was passed in US legislation. It requires all companies listed on the US stock market to determine the exact origin of minerals sourced from conflict areas and to reveal their supply chains to the US Securities and Exchange Commission. The goal was to end the illegal exploitation of minerals, to the interest of ending the ongoing conflict in DRC. In practice, the act created a defacto embargo on artisanal mining when two global coalitions of major electronic companies stopped buying minerals from smelters who couldn't prove that they did not source minerals that fund conflict in the DRC (Cuvelier et al. 2014; Seay 2012; Wimmer and Hilgert 2011). ${ }^{32}$

Although artisanal mining communities were affected by the embargo ${ }^{33}$, mineral trade did not stop entirely. First, minerals were smuggled across DRC's eastern borders (UN Security Council 2011). This was especially the case for gold, which is easy to conceal and for which most of the production was already smuggled out of the country before the introduction of Dodd-Frank (De Koning 2011; World Bank 2008). Second, Chinese buyers, who were not affected by the Dodd-Frank act, continued to export 3T minerals from the DRC (UN security council 2011: p.105). As such, research by the Southern Africa Research Watch indicates that buyers took advantage of the situation to buy minerals at heavily discounted prices from artisanal miners (Carisch 2012: p.15).

\footnotetext{
${ }^{32}$ The two coalitions are the Electronic Industry Citizenship Coalition (EICC - which includes a.o. Apple, HP, Dell and Microsoft), and the Global e-Sustainable Initiative (GeSI - which includes a.o. Motorola and Nokia). Because of this decision, the Malaysia Smelting Corporation (MSC), which previously purchased up to $80 \%$ of eastern Congolese tin, stopped sourcing minerals from the DRC.

${ }^{33}$ Qualitative evidence suggests that people in mining communities could no longer afford to visit healthcare facilities or pay for their children's schooling; moreover, the economic effects where felt throughout the eastern provinces as artisanal miners could no longer afford to pay for goods, services and agricultural products (Cuvelier et al. 2014; Geenen 2012; Seay 2012; Wimmer and Hilgert 2011). Using quantitative data, Parker et al. (2016) further find that the probability of infant deaths increased by at least $143 \%$ in villages near artisanal mines targeted by the Dodd-Frank act.
} 
The impact of Dodd-Frank on local conflict events is analyzed in detail by Parker and Vadheim (2017) and Stoop, Verpoorten, and Van der Windt (2018). Here, we implement two checks with respect Dodd-Frank. First, we simply drop the Dodd-Frank period from the analysis. Specifically, we drop all observations between July 2010 and December 2012. We end the Dodd-Frank period in December 2012, as several mining sites in North-Kivu, SouthKivu and Maniema had been validated 'conflict free' by that time. Moreover, by the end of 2012 local traders identified alternative markets for untagged minerals, allowing them to resume export (UN Security Council 2012). ${ }^{34}$ As a second check, we interact $\mathrm{ASM}_{\mathrm{i}}{ }^{*}$ price $\mathrm{t}_{\mathrm{t}}$ with an indicator variable that equals one for the Dodd-Frank period, and zero otherwise.

The results, presented in Tables A.2 and A.3, confirm our baseline findings. When looking at battles between armed actors, it should be noted that the estimated coefficients for the ASMprice interactions are about 50\% larger when dropping the Dodd-Frank period from the analysis. Moreover, while the estimated interaction effect between $\mathrm{ASM}_{\mathrm{i}}$ * price $\mathrm{t}$ and the Dodd-Frank period is negative for all outcome variables, it is only statistically significant for battles. The size of the interaction effect is practically the same as the estimated coefficient on $\mathrm{ASM}_{\mathrm{i}}{ }^{*}$ price $\mathrm{t}_{\mathrm{t}}$

These findings seem to suggest that, during the Dodd-Frank period, fluctuations in world mineral prices were less important in determining the value of local ASM sites. This resonates with the findings of Parker and Vadheim (2017) and Stoop, Verpoorten, and Van der Windt (2018). They argue that the introduction of the Dodd-Frank act led to a de-facto embargo on 3T, but not on gold as it easier to smuggle. As such, prices were not transmitted for 3T and ASM gold mines became more attractive - not because of an increase in gold prices - but

\footnotetext{
${ }^{34}$ Especially see pages 47, 48 and 193 of the report. For instance: "By 16 august 2012, thirteen tantalum smelters and refiners had been awarded 'conflict free' status” (UN security council 2012: p.193); “In July 2012, the Minister of Mines authorized all export houses, including Huaying and TTT/CCM, to export minerals that they purchased from Maniema ... The provincial Minister of Mines in North-Kivu extended the provision to also include validated mines in Masisi in a subsequent letter. Consequently, by the end of August 2012, Huaying had exported ... for a total of 248 tons of tin ore, up to and including 24 September 2012 ... TTT/CCM officially exported 86 tons of tin ore" (UN security council 2012: p.47); "In North Kivu, the export house AMR Mugote has lawfully exported minerals purchased from 'green' mine sites in Masisi” (UN security council 2012: p.47).
} 
because the relative value of these mines increased, since gold could be smuggled. As a result, battles between armed actors shifted toward relatively unregulated gold mining areas. 
TABLE A.2-EXCLUDING THE DODD-FRANK PERIOD

\begin{tabular}{|c|c|c|c|c|}
\hline & $\begin{array}{l}\text { Battles } \\
\text { (1) }\end{array}$ & $\begin{array}{l}\text { Violence } \\
\text { (2) }\end{array}$ & $\begin{array}{l}\text { Looting } \\
\text { (3) }\end{array}$ & $\begin{array}{l}\text { Riots } \\
(4)\end{array}$ \\
\hline ASM * price & $\begin{array}{c}0.0062 * * * \\
(0.0021)\end{array}$ & $\begin{array}{c}0.0039^{* *} \\
(0.0015)\end{array}$ & $\begin{array}{c}0.0017 * * \\
(0.0008)\end{array}$ & $\begin{array}{c}0.0009 \\
(0.0006)\end{array}$ \\
\hline LSM research * price & $\begin{array}{c}0.0015 \\
(0.0014)\end{array}$ & $\begin{array}{c}0.0011 \\
(0.0014)\end{array}$ & $\begin{array}{c}0.0004 \\
(0.0006)\end{array}$ & $\begin{array}{c}-0.0004 \\
(0.0003)\end{array}$ \\
\hline LSM production $*$ price & $\begin{array}{c}0.0055 \\
(0.0063)\end{array}$ & $\begin{array}{l}-0.0072 \\
(0.0073)\end{array}$ & $\begin{array}{c}0.0019 \\
(0.0026)\end{array}$ & $\begin{array}{c}0.0008 \\
(0.0030)\end{array}$ \\
\hline LSM research & $\begin{array}{l}-0.0001 \\
(0.0010)\end{array}$ & $\begin{array}{c}0.0000 \\
(0.0010)\end{array}$ & $\begin{array}{c}0.0002 \\
(0.0004)\end{array}$ & $\begin{array}{l}-0.0002 \\
(0.0004)\end{array}$ \\
\hline LSM production & $\begin{array}{c}-0.0279 * * * \\
(0.0091)\end{array}$ & $\begin{array}{l}-0.0003 \\
(0.0054)\end{array}$ & $\begin{array}{c}0.0024 \\
(0.0043)\end{array}$ & $\begin{array}{c}0.0141 * * \\
(0.0061)\end{array}$ \\
\hline LSM research in ASM & $\begin{array}{c}0.0001 \\
(0.0003)\end{array}$ & $\begin{array}{l}-0.0002 \\
(0.0003)\end{array}$ & $\begin{array}{l}-0.0001 \\
(0.0002)\end{array}$ & $\begin{array}{c}-0.0001 \\
(0.0001)\end{array}$ \\
\hline LSM production in ASM & $\begin{array}{c}0.0003 \\
(0.0011) \\
\end{array}$ & $\begin{array}{c}0.0040 * * * \\
(0.0011)\end{array}$ & $\begin{array}{c}0.0020^{* *} * \\
(0.0008)\end{array}$ & $\begin{array}{r}0.0006 \\
(0.0008) \\
\end{array}$ \\
\hline $\begin{array}{l}\text { Observations } \\
\text { Cell FE } \\
\text { Month FE }\end{array}$ & $\begin{array}{c}254,592 \\
\text { Yes } \\
\text { Yes }\end{array}$ & $\begin{array}{c}254,592 \\
\text { Yes } \\
\text { Yes }\end{array}$ & $\begin{array}{c}254,592 \\
\text { Yes } \\
\text { Yes }\end{array}$ & $\begin{array}{c}254,592 \\
\text { Yes } \\
\text { Yes }\end{array}$ \\
\hline
\end{tabular}

Notes: *** $\mathrm{p}<0.01, * * \mathrm{p}<0.05, * \mathrm{p}<0.1$; LPM estimations; Conley (1999) standard errors in parentheses, allowing for spatial correlation within a $500 \mathrm{~km}$. radius and infinite serial correlation; All observations during the Dodd-Frank period (July 2010 December 2012) are now dropped. 
TABLE A.3-ASM PRICE EFFECT DURING THE DODD-FrANK PERIOD

\begin{tabular}{lcccc}
\hline & $\begin{array}{c}\text { Battles } \\
(1)\end{array}$ & $\begin{array}{c}\text { Violence } \\
(2)\end{array}$ & $\begin{array}{c}\text { Looting } \\
(3)\end{array}$ & $\begin{array}{c}\text { Riots } \\
(4)\end{array}$ \\
\hline ASM * price & $0.0064^{* * *}$ & $0.0041^{* * *}$ & $0.0018^{* *}$ & $0.0009^{*}$ \\
& $(0.0020)$ & $(0.0016)$ & $(0.0008)$ & $(0.0005)$ \\
ASM * price X Dodd-Frank period & $-0.0062^{* * *}$ & -0.0010 & -0.0002 & -0.0006 \\
& $(0.0022)$ & $(0.0025)$ & $(0.0013)$ & $(0.0006)$ \\
LSM research * price & 0.0017 & 0.0011 & 0.0006 & -0.0003 \\
& $(0.0012)$ & $(0.0011)$ & $(0.0005)$ & $(0.0002)$ \\
LSM production * price & 0.0034 & -0.0059 & 0.0033 & 0.0023 \\
& $(0.0040)$ & $(0.0041)$ & $(0.0030)$ & $(0.0028)$ \\
LSM research & -0.0002 & -0.0000 & 0.0001 & -0.0002 \\
& $(0.0011)$ & $(0.0010)$ & $(0.0005)$ & $(0.0004)$ \\
LSM production & $-0.0269^{* * *}$ & 0.0026 & 0.0015 & $0.0119 * *$ \\
& $(0.0087)$ & $(0.0051)$ & $(0.0041)$ & $(0.0056)$ \\
LSM research in ASM & 0.0002 & -0.0000 & 0.0000 & -0.0002 \\
& $(0.0004)$ & $(0.0003)$ & $(0.0002)$ & $(0.0001)$ \\
LSM production in ASM & -0.0003 & $0.0026^{* * *}$ & $0.0015 *$ & 0.0006 \\
& $(0.0010)$ & $(0.0010)$ & $(0.0009)$ & $(0.0008)$ \\
\hline Observations & 313,344 & 313,344 & 313,344 & 313,344 \\
Cell FE & Yes & Yes & Yes & Yes \\
Month FE & Yes & Yes & Yes & Yes \\
\hline
\end{tabular}

Notes: *** $\mathrm{p}<0.01, * * \mathrm{p}<0.05, * \mathrm{p}<0.1$; LPM estimations; Conley (1999) standard errors in parentheses, allowing for spatial correlation within a $500 \mathrm{~km}$. radius and infinite serial correlation; Dodd-Frank period is an indicator variable that equals one for the period July 2010 - December 2012. 


\section{Appendix 3: Addressing reverse causality in the LSM expansion}

It is possible that the incidence of conflict affects the likelihood of LSM expansions. LSM companies may choose to invest in locations with little conflict, or at a time when conflict has abated. If industrial mining companies choose to expand their operations where or when conflict is relatively low, we would expect to find a negative relationship between conflict incidence and LSM expansion. However, we find that the expansion of LSM production activities is associated with an increase, rather than a decrease, in the incidence of violence against civilians, looting and riots (see Tables 2 and 3). In light of the endogeneity concerns posed by reverse causality, these results would constitute lower bounds of the actual effect, rather than false positives.

We do find a negative relationship between battle incidence and the start of LSM production activities. Yet, the data patterns go against the idea that companies choose to invest in cells with lower conflict levels. Panel A of Figure A.2 compares battle incidence across cells that are eventually covered by either a research or a production permit, thus cells that include mineral deposits suitable for LSM. We find that battle incidence is generally higher, rather than lower, in cells where LSM companies decide to move from the research to the production phase. While the average monthly battle incidence equals $0.4 \%$ for cells with only research concessions, it equals $0.8 \%$ for cells with a production concession. Furthermore, Panel B of Figure A.2 shows the evolution of battle incidence in the 36 months before and after the installment of an LSM production concession. The graph suggests that battle incidence decreases after, rather than before, companies decide to move from the research to the production phase. The horizontal lines in the Figure indicate the average monthly battle incidence, which equals $1.33 \%$ in the 36 months before the installment of an LSM production concession but drops to $0.57 \%$ in the following 36 months. 

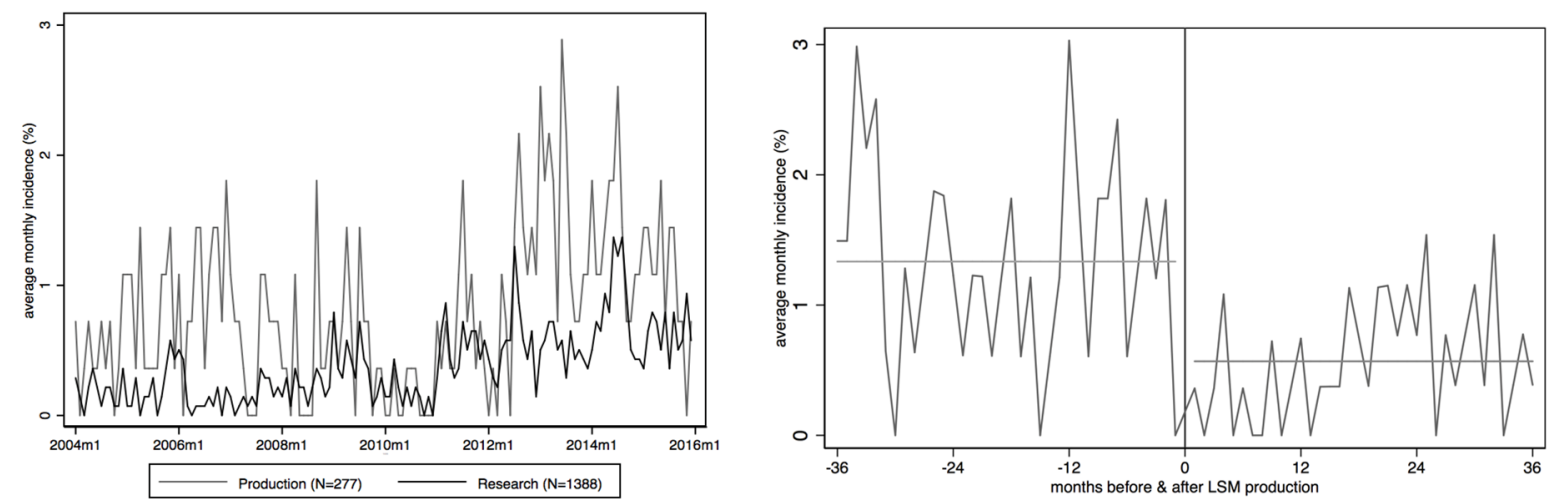

FIGURE A.1 EXPLORING THE RELATIONSHIP BETWEEN BATTLE INCIDENCE AND LSM EXPANSION

Notes: Panel A shows the evolution of battle events conditional on the presence of LSM, across cells that are eventually covered by an LSM production concessions and cells where only LSM research concessions are present. Panel B shows the evolution of battle events in the 36 months before and after the arrival of an LSM production concession for the 277 cells in our sample where companies eventually move to the production phase. The horizontal lines in Panel B indicate the average monthly battle incidence in the 36 months before and after the installment of an LSM production concession.

To further address the concern of reverse causality, we present results from three robustness checks. First, we show that the results are robust to the inclusion of dynamic and spatial conflict lags, effectively controlling for conflict incidence in a cell and its surrounding cells up to one year before the expansion of LSM. These lags capture the incidence of all types of conflict events (i.e. battles between armed actors, violence against civilians, looting and riots), thus taking into account that past battles may affect future violence against civilians, or the other way around. The dynamic conflict lags take the form of a dummy variable, which indicates if 
any of the conflict events took place within a cell in previous months. The spatial conflict lags indicate the number of adjacent cells that witnessed any of the conflict events in previous months. We control for contemporaneous conflict in adjacent cells as well as 12-month dynamic and spatial conflict lags. We realize that the coefficients on these dynamic and spatial lags may be estimated with bias. We only introduce them to check the robustness of our $\beta$ coefficients however. ${ }^{35}$ The results are presented in Table A.4. Adding this battery of lags only slightly changes the estimated coefficients on LSM Production ${ }_{i t}$. Most importantly, the estimated coefficient size on battles hardly changes: after controlling for dynamic and spatial conflict lags we still find a strong negative relationship between the expansion of LSM production concessions and the incidence of battles.

Second, the inclusion of month fixed effects allows us to control for all time-varying common shocks or trends that may impact conflict events and mining activities in Eastern Congo as a whole. In Table A.5, we address the concern that conflict in a specific region may have been trending up or down prior to the expansion of large-scale mining. To do so, we introduce province-specific linear time trends (our sample are comprises 11 provinces, see Figure 1). The results for LSM Production ${ }_{i t}$ are again highly comparable to the baseline estimates.

Third, we address the concern that cells where companies decide to invest may be different from other cells in ways that change over time and are not entirely captured by the inclusion of cell fixed effects. To do so, we re-estimate equation (3) on the restricted sample of cells where companies decided to invest. The results are presented in Table A.6 and are in line with the baseline estimates.

\footnotetext{
35 The introduction of lagged conflict variables gives rise to 'dynamic panel bias', i.e. the lags are correlated with the error term (Nickell 1981). Since we perform within-cell estimations, our estimates of the lags would understate the actual persistence of conflict. However, the bias is likely to be small since it decreases with the number of time periods, which is large in our case; i.e. 144 months (Roodman 2009). Introducing spatial lags gives rise to a simultaneity or reflection problem, since it is unclear if conflict in a specific cell is driven by conflict in adjacent cells, or the other way around (Anselin 2002; Manski 1993). A positive correlation of conflict across adjacent cells would overstate the estimated coefficients on the spatial conflict lags.
} 
TABLE A.4—CONTROLLING FOR 12-MONTH DYNAMIC AND SPATIAL CONFLICT LAGS

\begin{tabular}{lcccc}
\hline \hline & Battles & Violence & Looting & $(3)$ \\
& $(1)$ & $(2)$ & $\begin{array}{c}\text { Riots } \\
(4)\end{array}$ \\
\hline ASM * price & 0.0018 & $0.0020^{* *}$ & 0.0009 & 0.0001 \\
& $(0.0011)$ & $(0.0009)$ & $(0.0006)$ & $(0.0004)$ \\
LSM research * price & 0.0012 & 0.0004 & 0.0003 & $-0.0005^{* *}$ \\
& $(0.0008)$ & $(0.0007)$ & $(0.0004)$ & $(0.0002)$ \\
LSM production * price & 0.0051 & -0.0057 & 0.0039 & 0.0030 \\
& $(0.0037)$ & $(0.0041)$ & $(0.0031)$ & $(0.0029)$ \\
LSM research & -0.0000 & 0.0003 & 0.0002 & -0.0005 \\
& $(0.0008)$ & $(0.0007)$ & $(0.0004)$ & $(0.0004)$ \\
LSM production & $-0.0239^{* * *}$ & $0.0096^{*}$ & 0.0031 & $0.0136^{* *}$ \\
& $(0.0078)$ & $(0.0055)$ & $(0.0041)$ & $(0.0054)$ \\
LSM research in ASM & 0.0003 & -0.0002 & 0.0000 & $-0.0002^{*}$ \\
& $(0.0003)$ & $(0.0002)$ & $(0.0002)$ & $(0.0001)$ \\
LSM production in ASM & -0.0009 & $0.0023^{* * *}$ & $0.0014 *$ & 0.0004 \\
& $(0.0008)$ & $(0.0007)$ & $(0.0008)$ & $(0.0007)$ \\
\hline Observations & 287,232 & 287,232 & 287,232 & 287,232 \\
Cell FE & Yes & Yes & Yes & Yes \\
Month FE & Yes & Yes & Yes & Yes \\
12-month dynamic conflict lags & Yes & Yes & Yes & Yes \\
12-month spatial conflict lags & Yes & Yes & Yes & Yes \\
\hline
\end{tabular}

Notes: *** $\mathrm{p}<0.01, * * \mathrm{p}<0.05, * \mathrm{p}<0.1$; LPM estimations; Conley (1999) standard errors in parentheses, allowing for spatial correlation within a $500 \mathrm{~km}$. radius and infinite serial correlation; All specifications now include 12-month dynamic and spatial conflict lags. 
TABLE A.5-CONTROLLING FOR PROVINCE-SPECIFIC LINEAR TIME TRENDS

\begin{tabular}{lcccc}
\hline \hline & Battles & Violence & Looting & $(3)$ \\
& $(1)$ & $(2)$ & $\begin{array}{c}\text { Riots } \\
(4)\end{array}$ \\
\hline ASM * price & 0.0016 & 0.0018 & 0.0007 & -0.0004 \\
& $(0.0014)$ & $(0.0013)$ & $(0.0007)$ & $(0.0005)$ \\
LSM research * price & 0.0016 & 0.0012 & 0.0008 & -0.0002 \\
& $(0.0012)$ & $(0.0011)$ & $(0.0005)$ & $(0.0003)$ \\
LSM production * price & 0.0017 & -0.0062 & 0.0027 & 0.0019 \\
& $(0.0040)$ & $(0.0041)$ & $(0.0030)$ & $(0.0028)$ \\
LSM research & 0.0011 & 0.0010 & 0.0005 & 0.0004 \\
& $(0.0011)$ & $(0.0010)$ & $(0.0004)$ & $(0.0004)$ \\
LSM production & $-0.0235^{* *}$ & -0.0062 & -0.0026 & $0.0098^{*}$ \\
& $(0.0092)$ & $(0.0064)$ & $(0.0037)$ & $(0.0056)$ \\
LSM research in ASM & -0.0001 & -0.0004 & -0.0001 & $-0.0003^{* *}$ \\
& $(0.0004)$ & $(0.0004)$ & $(0.0002)$ & $(0.0002)$ \\
LSM production in ASM & 0.0000 & $0.0025 * * *$ & $0.0014 *$ & 0.0006 \\
& $(0.0011)$ & $(0.0010)$ & $(0.0008)$ & $(0.0008)$ \\
\hline Observations & 313,344 & 313,344 & 313,344 & 313,344 \\
Cell FE & Yes & Yes & Yes & Yes \\
Month FE & Yes & Yes & Yes & Yes \\
Province-specific linear time trends & Yes & Yes & Yes & Yes \\
\hline
\end{tabular}

Notes: *** $\mathrm{p}<0.01, * * \mathrm{p}<0.05, * \mathrm{p}<0.1$; LPM estimations; Conley (1999) standard errors in parentheses, allowing for spatial correlation within a $500 \mathrm{~km}$. radius and infinite serial correlation; All specifications now additionally include province-specific linear time trends. 
TABLE A.6-ESTIMATION ON RESTRICTED SAMPLE OF CELLS WITH LSM PRODUCTION CONCESSIONS

\begin{tabular}{lcccc}
\hline \hline & $\begin{array}{c}\text { Battles } \\
(1)\end{array}$ & $\begin{array}{c}\text { Violence } \\
(2)\end{array}$ & $\begin{array}{c}\text { Looting } \\
(3)\end{array}$ & $\begin{array}{c}\text { Riots } \\
(4)\end{array}$ \\
\hline ASM * price & -0.0002 & 0.0025 & 0.0015 & 0.0004 \\
& $(0.0017)$ & $(0.0018)$ & $(0.0014)$ & $(0.0011)$ \\
LSM research * price & 0.0044 & 0.0008 & -0.0008 & -0.0007 \\
& $(0.0045)$ & $(0.0030)$ & $(0.0010)$ & $(0.0008)$ \\
LSM production * price & 0.0053 & -0.0049 & 0.0045 & 0.0031 \\
& $(0.0042)$ & $(0.0049)$ & $(0.0032)$ & $(0.0029)$ \\
LSM research & -0.0058 & -0.0032 & -0.0006 & -0.0020 \\
& $(0.0036)$ & $(0.0047)$ & $(0.0027)$ & $(0.0025)$ \\
LSM production & $-0.0261^{* * *}$ & 0.0046 & 0.0020 & $0.0113^{* *}$ \\
& $(0.0080)$ & $(0.0059)$ & $(0.0043)$ & $(0.0051)$ \\
LSM research in ASM & $0.0014 * *$ & 0.0004 & 0.0001 & -0.0002 \\
& $(0.0007)$ & $(0.0007)$ & $(0.0003)$ & $(0.0002)$ \\
LSM production in ASM & -0.0001 & $0.0025^{* * *}$ & $0.0015 *$ & 0.0006 \\
& $(0.0010)$ & $(0.0009)$ & $(0.0008)$ & $(0.0008)$ \\
\hline Observations & 39,888 & 39,888 & 39,888 & 39,888 \\
Cell FE & Yes & Yes & Yes & Yes \\
Month FE & Yes & Yes & Yes & Yes \\
\hline
\end{tabular}

Notes: *** $\mathrm{p}<0.01, * * \mathrm{p}<0.05, * \mathrm{p}<0.1$; LPM estimations; Conley (1999) standard errors in parentheses, allowing for spatial correlation within a $500 \mathrm{~km}$. radius and infinite serial correlation; We now re-estimate equation (3) on the restricted sample of cells that ever have an LSM production concession. 


\section{Appendix 4: Robustness}

\section{A. Spatial correlation}

We test the robustness of the results to using alternative spatial and temporal specifications when correcting the standard errors (see Table A.7). For each estimated coefficient, we present

five sets of standard errors: 1) Clustering the standard errors at the level of the cell; 2) Conley standard errors allowing for spatial correlation within a $1,000 \mathrm{~km}$ radius and for infinite serial correlation; 3) Conley standard errors allowing for spatial correlation within a $100 \mathrm{~km}$ radius and for infinite serial correlation; 4) Conley standard errors allowing for spatial correlation within a $100 \mathrm{~km}$ radius and for 5 years of serial correlation; 5) Conley standard errors allowing for spatial correlation within a $100 \mathrm{~km}$ radius and for 1 year of serial correlation. The results are robust across these alternative specifications. 
TABLE A.7-STANDARD ERRORS

\begin{tabular}{|c|c|c|c|c|c|c|c|}
\hline Variable of interest: & $\begin{array}{l}\text { ASM } \\
* \text { price }\end{array}$ & $\begin{array}{l}\text { LSMr } \\
* \text { price } \\
\end{array}$ & $\begin{array}{l}\text { LSMp } \\
* \text { price } \\
\end{array}$ & LSMr & LSMp & $\begin{array}{c}\text { LSMr } \\
\text { in ASM } \\
\end{array}$ & $\begin{array}{l}\text { LSMp } \\
\text { in ASM } \\
\end{array}$ \\
\hline Dependent variable: Battles & 0.0040 & 0.0017 & 0.0031 & -0.0002 & -0.0263 & 0.0003 & -0.0002 \\
\hline Cell-level & $(0.0016)$ & $(0.0012)$ & $(0.0040)$ & $(0.0011)$ & $(0.0086)$ & $(0.0004)$ & $(0.0010)$ \\
\hline Spatial: $1,000 \mathrm{~km}$. Time: infinite & $(0.0016)$ & $(0.0012)$ & $(0.0040)$ & $(0.0011)$ & $(0.0086)$ & $(0.0004)$ & $(0.0010)$ \\
\hline Spatial: $100 \mathrm{~km}$. Time: infinite & $(0.0016)$ & $(0.0012)$ & $(0.0040)$ & $(0.0011)$ & $(0.0087)$ & $(0.0004)$ & $(0.0010)$ \\
\hline Spatial: $100 \mathrm{~km}$. Time: 5 years & $(0.0011)$ & $(0.0008)$ & $(0.0037)$ & $(0.0008)$ & $(0.0074)$ & $(0.0003)$ & $(0.0011)$ \\
\hline Spatial: $100 \mathrm{~km}$. Time: 1 year & $(0.0009)$ & $(0.0006)$ & $(0.0040)$ & $(0.0007)$ & $(0.0066)$ & $(0.0002)$ & $(0.0012)$ \\
\hline Dependent variable: Violence & 0.0037 & 0.0011 & -0.0059 & -0.0000 & 0.0026 & -0.0000 & 0.0026 \\
\hline Cell-level & $(0.0013)$ & $(0.0011)$ & $(0.0040)$ & $(0.0010)$ & $(0.0051)$ & $(0.0003)$ & $(0.0009)$ \\
\hline Spatial: $1,000 \mathrm{~km}$. Time: infinite & $(0.0013)$ & $(0.0011)$ & $(0.0041)$ & $(0.0010)$ & $(0.0051)$ & $(0.0003)$ & $(0.0010)$ \\
\hline Spatial: $100 \mathrm{~km}$. Time: infinite & $(0.0013)$ & $(0.0011)$ & $(0.0040)$ & $(0.0010)$ & $(0.0051)$ & $(0.0003)$ & $(0.0010)$ \\
\hline Spatial: $100 \mathrm{~km}$. Time: 5 years & $(0.0010)$ & $(0.0008)$ & $(0.0038)$ & $(0.0008)$ & $(0.0052)$ & $(0.0003)$ & $(0.0012)$ \\
\hline Spatial: $100 \mathrm{~km}$. Time: 1 year & $(0.0008)$ & $(0.0006)$ & $(0.0036)$ & $(0.0007)$ & $(0.0054)$ & $(0.0002)$ & $(0.0011)$ \\
\hline Dependent variable: Looting & 0.0017 & 0.0006 & 0.0033 & 0.0001 & 0.0015 & 0.0000 & 0.0015 \\
\hline Cell-level & $(0.0007)$ & $(0.0005)$ & $(0.0031)$ & $(0.0004)$ & $(0.0042)$ & $(0.0002)$ & $(0.0008)$ \\
\hline Spatial: $1,000 \mathrm{~km}$. Time: infinite & $(0.0008)$ & $(0.0005)$ & $(0.0030)$ & $(0.0005)$ & $(0.0041)$ & $(0.0002)$ & $(0.0009)$ \\
\hline Spatial: $100 \mathrm{~km}$. Time: infinite & $(0.0008)$ & $(0.0005)$ & $(0.0031)$ & $(0.0004)$ & $(0.0042)$ & $(0.0002)$ & $(0.0009)$ \\
\hline Spatial: $100 \mathrm{~km}$. Time: 5 years & $(0.0006)$ & $(0.0004)$ & $(0.0026)$ & $(0.0004)$ & $(0.0040)$ & $(0.0001)$ & $(0.0008)$ \\
\hline Spatial: $100 \mathrm{~km}$. Time: 1 year & $(0.0005)$ & $(0.0003)$ & $(0.0024)$ & $(0.0003)$ & $(0.0036)$ & $(0.0001)$ & $(0.0007)$ \\
\hline Dependent variable: Riots & 0.0007 & -0.0003 & 0.0023 & -0.0002 & 0.0120 & -0.0001 & 0.0006 \\
\hline Cell-level & $(0.0005)$ & $(0.0002)$ & $(0.0029)$ & $(0.0004)$ & $(0.0056)$ & $(0.0001)$ & $(0.0009)$ \\
\hline Spatial: $1,000 \mathrm{~km}$. Time: infinite & $(0.0005)$ & $(0.0002)$ & $(0.0028)$ & $(0.0004)$ & $(0.0056)$ & $(0.0001)$ & $(0.0008)$ \\
\hline Spatial: $100 \mathrm{~km}$. Time: infinite & $(0.0005)$ & $(0.0002)$ & $(0.0028)$ & $(0.0004)$ & $(0.0056)$ & $(0.0001)$ & $(0.0009)$ \\
\hline Spatial: $100 \mathrm{~km}$. Time: 5 years & $(0.0003)$ & $(0.0002)$ & $(0.0027)$ & $(0.0003)$ & $(0.0051)$ & $(0.0001)$ & $(0.0005)$ \\
\hline Spatial: $100 \mathrm{~km}$. Time: 1 year & $(0.0003)$ & $(0.0002)$ & $(0.0024)$ & $(0.0003)$ & $(0.0044)$ & $(0.0001)$ & $(0.0003)$ \\
\hline Territory FE & Yes & Yes & Yes & Yes & Yes & Yes & Yes \\
\hline Month FE & Yes & Yes & Yes & Yes & Yes & Yes & Yes \\
\hline Observations & 313,344 & 313,344 & 313,344 & 313,344 & 313,344 & 313,344 & 313,344 \\
\hline
\end{tabular}

Notes: LPM estimations. We test the robustness of the main results to using alternative spatial and temporal specifications when correcting the standard errors. For each estimated coefficient, we present five sets of standard errors in parentheses: 1) Clustering the standard errors at the level of the cell 2) Conley standard errors allowing for spatial correlation within a 1,000 km radius and for infinite serial correlation; 3) Conley standard errors allowing for spatial correlation within a $100 \mathrm{~km}$ radius and for infinite serial correlation; 4) Conley standard errors allowing for spatial correlation within a $100 \mathrm{~km}$ radius and for 5 years of serial correlation; 5) Conley standard errors allowing for spatial correlation within a $100 \mathrm{~km}$ radius and for 1 year of serial correlation. 


\section{B. Spatial spillovers}

Conflicts may diffuse spatially. We explore spatial spillovers in two ways.

First, we follow the same approach as taken by Berman et al. (2017) and additionally control for the number of neighboring cells that are in conflict. This variable captures the incidence of all types of conflict events (i.e. battles between armed actors, violence against civilians, looting and riots), thus taking into account that e.g. battles in neighboring cells of cell i may affect violence against civilians in cell $\mathrm{i}$, or the other way around.

The results are presented in Table A.8. In Panel A, we find that the main results remain similar to those originally reported. Moreover, for all types of conflict events, spatial spillovers from neighboring cells are positive and strongly significant. In Panel B, we further include time lags of the number of neighboring cells in conflict. Here we find that spatial spillovers from neighboring cells lose significance after 3-month time lags. Again, the main results remain similar.

While informative, these results have to be interpreted with caution. Introducing spatial conflict lags gives rise to a simultaneity or reflection problem, since it is unclear if conflict in a specific cell is driven by conflict in neighboring cells, or the other way around (Anselin 2002; Manski 1993). A positive correlation of conflict across neighboring cells overstates the estimated coefficients on the spatial conflict lags. 
TABLE A.8-SPATIAL SPILLOVERS 1

\begin{tabular}{|c|c|c|c|c|c|c|c|c|}
\hline & \multicolumn{4}{|c|}{$\mathrm{A}$} & \multicolumn{4}{|c|}{ B } \\
\hline & $\begin{array}{c}\text { Battles } \\
\text { (1) }\end{array}$ & $\begin{array}{c}\text { Violence } \\
\text { (2) }\end{array}$ & $\begin{array}{l}\text { Looting } \\
\text { (3) }\end{array}$ & $\begin{array}{l}\text { Riots } \\
\text { (4) }\end{array}$ & $\begin{array}{c}\text { Battles } \\
(5)\end{array}$ & $\begin{array}{l}\text { Violence } \\
(6)\end{array}$ & $\begin{array}{l}\text { Looting } \\
(7)\end{array}$ & $\begin{array}{l}\text { Riots } \\
(8)\end{array}$ \\
\hline \multirow[t]{2}{*}{ ASM $*$ price } & $0.0032 * *$ & $0.0032 * *$ & $0.0014^{*}$ & 0.0006 & $0.0028^{*}$ & $0.0027 * *$ & $0.0012 *$ & 0.0005 \\
\hline & $(0.0015)$ & $(0.0013)$ & $(0.0007)$ & $(0.0005)$ & $(0.0015)$ & $(0.0013)$ & $(0.0007)$ & $(0.0005)$ \\
\hline \multirow[t]{2}{*}{ LSM research * price } & 0.0018 & 0.0012 & 0.0006 & -0.0003 & 0.0018 & 0.0011 & 0.0006 & -0.0003 \\
\hline & $(0.0012)$ & $(0.0011)$ & $(0.0005)$ & $(0.0002)$ & $(0.0011)$ & $(0.0011)$ & $(0.0005)$ & $(0.0002)$ \\
\hline \multirow[t]{2}{*}{ LSM production * price } & 0.0035 & -0.0056 & 0.0034 & 0.0024 & 0.0038 & -0.0051 & 0.0036 & 0.0025 \\
\hline & $(0.0040)$ & $(0.0041)$ & $(0.0030)$ & $(0.0028)$ & $(0.0039)$ & $(0.0040)$ & $(0.0031)$ & $(0.0029)$ \\
\hline \multirow[t]{2}{*}{ LSM research } & -0.0000 & 0.0001 & 0.0002 & -0.0002 & 0.0002 & 0.0003 & 0.0003 & -0.0002 \\
\hline & $(0.0010)$ & $(0.0010)$ & $(0.0004)$ & $(0.0004)$ & $(0.0010)$ & $(0.0011)$ & $(0.0005)$ & $(0.0004)$ \\
\hline \multirow[t]{2}{*}{ LSM production } & $-0.0253 * * *$ & 0.0033 & 0.0019 & $0.0121 * *$ & $-0.0253 * * *$ & 0.0038 & 0.0020 & $0.0123 * *$ \\
\hline & $(0.0082)$ & $(0.0050)$ & $(0.0042)$ & $(0.0056)$ & $(0.0087)$ & $(0.0051)$ & $(0.0042)$ & $(0.0056)$ \\
\hline \multirow[t]{2}{*}{ LSM research in ASM } & 0.0003 & -0.0000 & 0.0000 & -0.0001 & 0.0003 & -0.0000 & 0.0000 & -0.0002 \\
\hline & $(0.0004)$ & $(0.0004)$ & $(0.0002)$ & $(0.0001)$ & $(0.0004)$ & $(0.0004)$ & $(0.0002)$ & $(0.0001)$ \\
\hline \multirow[t]{2}{*}{ LSM production in ASM } & -0.0003 & $0.0025 * * *$ & $0.0015^{*}$ & 0.0006 & -0.0004 & $0.0025 * *$ & $0.0015^{*}$ & 0.0006 \\
\hline & $(0.0010)$ & $(0.0010)$ & $(0.0009)$ & $(0.0009)$ & $(0.0011)$ & $(0.0010)$ & $(0.0009)$ & $(0.0008)$ \\
\hline \multirow[t]{2}{*}{ \# neighboring cells in conflict } & $0.1512 * * *$ & $0.0971 * * *$ & $0.0470 * * *$ & $0.0217 * * *$ & $0.1351 * * *$ & $0.0768 * * *$ & $0.0395 * * *$ & $0.0150 * *$ \\
\hline & $(0.0235)$ & $(0.0182)$ & $(0.0106)$ & $(0.0074)$ & $(0.0222)$ & $(0.0159)$ & $(0.0093)$ & $(0.0063)$ \\
\hline \# neighboring cells in conflict & & & & & $0.0478 * * *$ & $0.0462 * * *$ & $0.0142 * *$ & $0.0145 * *$ \\
\hline 1-month lag & & & & & $(0.0120)$ & $(0.0122)$ & $(0.0069)$ & $(0.0059)$ \\
\hline \# neighboring cells in conflict & & & & & 0.0097 & $0.0252 * * *$ & $0.0173 * *$ & $0.0147 *$ \\
\hline 2-month lag & & & & & $(0.0113)$ & $(0.0091)$ & $(0.0069)$ & $(0.0078)$ \\
\hline \# neighboring cells in conflict & & & & & 0.0101 & $0.0217 * *$ & 0.0067 & 0.0050 \\
\hline 3-month lag & & & & & $(0.0099)$ & $(0.0094)$ & $(0.0055)$ & $(0.0045)$ \\
\hline \# neighboring cells in conflict & & & & & 0.0136 & 0.0067 & -0.0026 & -0.0029 \\
\hline 4-month lag & & & & & $(0.0101)$ & $(0.0105)$ & $(0.0064)$ & $(0.0040)$ \\
\hline Observations & 313,344 & 313,344 & 313,344 & 313,344 & 304,640 & 304,640 & 304,640 & 304,640 \\
\hline Cell FE & Yes & Yes & Yes & Yes & Yes & Yes & Yes & Yes \\
\hline Month FE & Yes & Yes & Yes & Yes & Yes & Yes & Yes & Yes \\
\hline
\end{tabular}

Notes: $* * * \mathrm{p}<0.01, * * \mathrm{p}<0.05, * \mathrm{p}<0.1$; LPM estimations; Conley (1999) standard errors in parentheses, allowing for spatial correlation within a $500 \mathrm{~km}$. radius and infinite serial correlation; In Panel A we additionally control for the number of neighboring cells in conflict; In Panel B we further control for 4-month time-lags of this this variable. 
Second, in our main analysis we find that the expansion of LSM production activities impacts conflict events in the vicinity of the mining concession (Table 3). Specifically, we find that it is associated with a decrease in battles and an increase in riots. Moreover, when LSM production activities expand into areas in use by artisanal miners, we find that it increases violence against civilians and looting. We now explore whether the expansion of LSM production activities also has an impact on conflict events in the wider geographical area surrounding mining concessions.

We created two additional variables that capture the expansion of LSM production activities in neighboring cells. 'LSM Production Neighbor ${ }_{i t}$ ' is defined like 'LSM Production ${ }_{i t}$ ' and indicates the share of the surface area that is covered by production concessions - but now for all neighboring cells of cell i. Similarly, 'LSMP in ASM Neighbor ${ }_{\mathrm{it}}$ ' is defined like 'LSMP in ASM $_{\mathrm{it}}$ ' and indicates - for all neighboring cells of cell $\mathrm{i}$ - the average number of artisanal mining sites that is encompassed by an LSM production concession. To explore the extent of spatial diffusion, we create these variables both for first- and second-degree neighbors of each cell (see Figure A.2).

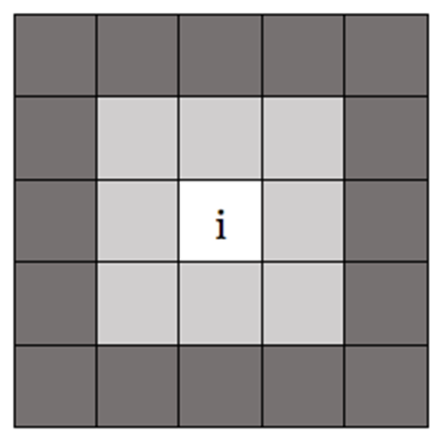

FIGURE A.2 NEIGHBORING CELLS

Notes: Cells marked light gray are $1^{\text {st }}$ degree neighboring cells of cell $\mathrm{i}$, while $2^{\text {nd }}$ degree neighboring cells are indicated dark grey. Cells are approximately $25 \times 25$ kilometers. Hence, $1^{\text {st }}$ degree neighboring cells are located within a 25 -kilometer radius around cell i, while $2^{\text {nd }}$ degree neighboring cells are located within a 50-kilometer radius around cell i.

We are interested in analyzing whether the expansion of LSM production activities impacts conflict events in neighboring cells without an industrial mining concession. We therefore 
augment equation (2) with the above variables and estimate it on the subsample of cells that never encompass an LSM production concession during our study period (87\% of all cells). The adapted equation takes the following form:

$$
\begin{aligned}
& \text { Conflict }_{i t}=\delta_{i}+\mu_{\mathrm{t}}+\beta_{1} \text { ASM }_{\mathrm{i}} * \text { price }_{\mathrm{t}}+\beta_{2} \text { LSM Research }_{\mathrm{it}} * \text { price }_{\mathrm{t}}+\beta_{3} \text { LSM Research }_{\mathrm{it}}+\beta_{4} \\
& \text { LSM Production Neighbor } 1_{i t}+\beta_{5} \text { LSM Production Neighbor } 2_{i t}+\beta_{6} \text { LSMP in ASM } \\
& \text { Neighbor } 1_{\mathrm{it}}+\beta_{7} \text { LSMP in ASM Neighbor } 2_{\mathrm{it}}+\varepsilon_{\mathrm{it}}{ }^{36}
\end{aligned}
$$

Table A.9 presents the results. In Panel A, we find that the protection effect of LSM also extends to $1^{\text {st }}$ degree neighbors. Specifically, an expansion in LSM production activities is associated with a decrease in the incidence of battles in neighboring cells without an LSM concession. We further note that an LSM production expansion has no significant impact on the incidence of riots in neighboring cells where LSM is not present or has not moved to the production phase; i.e. where local communities are less likely to be directly affected. However, when LSM production activities expand into areas already in use by artisanal miners, violence against civilians and looting also spills over to $1^{\text {st }}$ degree neighboring cells without LSM concessions. In Panel B, we check whether these findings also extend to $2^{\text {nd }}$ degree neighboring cells, but do not find any significant impact.

\footnotetext{
${ }^{36}$ Since we estimate the equation on the subsample of cells that never encompass an LSM production concession, 'LSM Production ${ }_{\mathrm{it}}$ ' and

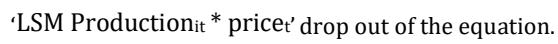


TABLE A.9-SPATIAL SPILLOVERS 2

\begin{tabular}{|c|c|c|c|c|c|c|c|c|}
\hline & \multicolumn{4}{|c|}{ A } & \multicolumn{4}{|c|}{$\mathrm{B}$} \\
\hline & $\begin{array}{c}\text { Battles } \\
\text { (1) }\end{array}$ & $\begin{array}{c}\text { Violence } \\
(2)\end{array}$ & $\begin{array}{c}\text { Looting } \\
\text { (3) }\end{array}$ & $\begin{array}{l}\text { Riots } \\
(4)\end{array}$ & $\begin{array}{c}\text { Battles } \\
(5)\end{array}$ & $\begin{array}{c}\text { Violence } \\
(6)\end{array}$ & $\begin{array}{c}\text { Looting } \\
(7)\end{array}$ & $\begin{array}{l}\text { Riots } \\
(8)\end{array}$ \\
\hline \multirow{2}{*}{$\mathrm{ASM} *$ price } & $0.0061 * * *$ & $0.0042 * *$ & $0.0019 * *$ & $0.0008 *$ & $0.0061 * * *$ & $0.0043^{* * * *}$ & $0.0019 * *$ & $0.0008 *$ \\
\hline & $(0.0020)$ & $(0.0016)$ & $(0.0008)$ & $(0.0005)$ & $(0.0020)$ & $(0.0016)$ & $(0.0008)$ & $(0.0005)$ \\
\hline \multirow[t]{2}{*}{ LSM research $*$ price } & 0.0014 & 0.0013 & 0.0007 & -0.0003 & 0.0014 & 0.0013 & 0.0007 & -0.0003 \\
\hline & $(0.0012)$ & $(0.0012)$ & $(0.0005)$ & $(0.0002)$ & $(0.0012)$ & $(0.0012)$ & $(0.0005)$ & $(0.0002)$ \\
\hline \multirow[t]{2}{*}{ LSM research } & 0.0000 & 0.0002 & 0.0001 & -0.0001 & -0.0000 & 0.0003 & 0.0001 & -0.0001 \\
\hline & $(0.0011)$ & $(0.0010)$ & $(0.0004)$ & $(0.0003)$ & $(0.0011)$ & $(0.0010)$ & $(0.0004)$ & $(0.0003)$ \\
\hline \multirow[t]{2}{*}{ LSM production, $1^{\text {st }}$ degree neighbors } & $-0.0887 * *$ & 0.0559 & 0.0104 & 0.0127 & $-0.0868 *$ & 0.0137 & 0.0124 & 0.0069 \\
\hline & $(0.0418)$ & $(0.0429)$ & $(0.0172)$ & $(0.0162)$ & $(0.0475)$ & $(0.0441)$ & $(0.0182)$ & $(0.0188)$ \\
\hline \multirow[t]{2}{*}{ LSM production in ASM, $1^{\text {st }}$ degree neighbors } & -0.0002 & $0.0058 * *$ & $0.0035^{* *}$ & 0.0010 & -0.0007 & $0.0057 * *$ & $0.0034 * *$ & 0.0009 \\
\hline & $(0.0021)$ & $(0.0025)$ & $(0.0014)$ & $(0.0008)$ & $(0.0022)$ & $(0.0025)$ & $(0.0014)$ & $(0.0009)$ \\
\hline \multirow[t]{2}{*}{ LSM production, $2^{\text {nd }}$ degree neighbors } & & & & & -0.0114 & 0.0342 & -0.0032 & 0.0034 \\
\hline & & & & & $(0.0241)$ & $(0.0391)$ & $(0.0165)$ & $(0.0089)$ \\
\hline \multirow[t]{2}{*}{ LSM production in ASM, $2^{\text {nd }}$ degree neighbors } & & & & & 0.0027 & 0.0006 & 0.0004 & 0.0005 \\
\hline & & & & & $(0.0026)$ & $(0.0020)$ & $(0.0012)$ & $(0.0009)$ \\
\hline Observations & 273,456 & 273,456 & 273,456 & 273,456 & 273,456 & 273,456 & 273,456 & 273,456 \\
\hline Cell FE & Yes & Yes & Yes & Yes & Yes & Yes & Yes & Yes \\
\hline Month FE & Yes & Yes & Yes & Yes & Yes & Yes & Yes & Yes \\
\hline
\end{tabular}

Notes: $* * * \mathrm{p}<0.01, * * \mathrm{p}<0.05, * \mathrm{p}<0.1$; LPM estimations on the subsample of cells that never encompass an LSM production concession during our study period (87\% of cells); Conley (1999) standard errors in parentheses, allowing for spatial correlation within a $500 \mathrm{~km}$. radius and infinite serial correlation; In Panel A we estimate equation (2) while additionally controlling for the expansion of LSM production activities in $1^{\text {st }}$ degree adjacent cells; In Panel B we further control for the expansion of LSM production activities in $2^{\text {nd }}$ degree adjacent cells.

\section{Conflict intensity}

The main results explore conflict incidence. As a sensitivity check, we now explore various measures of conflict intensity.

First, we replace the monthly dummy variables for battles, violence against civilians, looting and riots with variables that count the number of times these conflict events occurred in a specific cell and month. ACLED measures conflict as atomic events; i.e. extended events are measured as separate incidents for each day that they persist (Raleigh and Dowd 2016). Such overreporting of extended events causes the distribution of conflict events to be right-skewed. Following the example of Berman et al. (2017), we employ two methods to deal with outliers. First, we drop the top 5\% values of the non-zero observations. In the case of battles, for instance, this entails dropping only $0.003 \%$ of the total sample. Second, among the non-zero observations, we drop values that are more than two standard deviations above the mean. In the 
case of battles, this entails dropping $0.002 \%$ of the total sample. Both methods yield similar results, we only report those for the former. The results are presented in Columns (1) to (4) of Table A.10.

Second, we employ the crude information that ACLED provides on the number of fatalities associated with conflict events. We create two additional dependent variables: a dummy variable that indicates the monthly incidence of events with at least one fatality and a variable that counts the number of times such events occurred in a specific cell and month. Again, we deal with outliers by dropping the top $5 \%$ values of the non-zero observations. The results are presented in Columns (5) and (6) of Table A.10.

All results are in line with the main findings. A surge in ASM mineral prices increases the number of battles, violence against civilians and looting events. No such relationship is found for LSM. The start of LSM production activities is associated with a decrease in the number of battles, but an increase in the number of riots; and when these activities crowd out ASM, the number of events measuring violence against civilians and looting increases. A surge in ASM mineral prices also increases the likelihood and number of fatal conflict events. The start of LSM production activities is associated with a decrease in the likelihood and number of fatal conflict events. However, when LSM crowds out ASM, the likelihood of fatal conflict events rises. 
TABLE A.10-CONFLICT INTENSITY

\begin{tabular}{|c|c|c|c|c|c|c|}
\hline & \multicolumn{4}{|c|}{ Number of conflict events } & \multicolumn{2}{|c|}{ Fatal events } \\
\hline & $\begin{array}{c}\text { Battles } \\
\text { (1) }\end{array}$ & $\begin{array}{c}\text { Violence } \\
\text { (2) }\end{array}$ & $\begin{array}{l}\text { Looting } \\
\text { (3) }\end{array}$ & $\begin{array}{l}\text { Riots } \\
(4)\end{array}$ & $\begin{array}{c}\text { Incidence } \\
\text { (5) }\end{array}$ & $\begin{array}{l}\text { Nr. events } \\
\text { (6) }\end{array}$ \\
\hline $\mathrm{ASM} *$ price & $\begin{array}{c}0.0059 * * \\
(0.0025)\end{array}$ & $\begin{array}{c}0.0052 * * * \\
(0.0017)\end{array}$ & $\begin{array}{c}0.0021^{* *} \\
(0.0008)\end{array}$ & $\begin{array}{c}0.0007 \\
(0.0005)\end{array}$ & $\begin{array}{c}0.0029^{* *} \\
(0.0012)\end{array}$ & $\begin{array}{l}0.0158^{*} \\
(0.0087)\end{array}$ \\
\hline LSM research * price & $\begin{array}{c}0.0029 \\
(0.0021)\end{array}$ & $\begin{array}{c}0.0018 \\
(0.0016)\end{array}$ & $\begin{array}{c}0.0008 \\
(0.0005)\end{array}$ & $\begin{array}{c}-0.0003 \\
(0.0002)\end{array}$ & $\begin{array}{c}0.0003 \\
(0.0007)\end{array}$ & $\begin{array}{c}0.0031 \\
(0.0059)\end{array}$ \\
\hline LSM production * price & $\begin{array}{c}0.0024 \\
(0.0054)\end{array}$ & $\begin{array}{l}-0.0087 \\
(0.0066)\end{array}$ & $\begin{array}{c}0.0033 \\
(0.0036)\end{array}$ & $\begin{array}{c}0.0028 \\
(0.0032)\end{array}$ & $\begin{array}{c}0.0005 \\
(0.0026)\end{array}$ & $\begin{array}{c}0.0009 \\
(0.0195)\end{array}$ \\
\hline LSM research & $\begin{array}{l}-0.0011 \\
(0.0016)\end{array}$ & $\begin{array}{l}-0.0005 \\
(0.0014)\end{array}$ & $\begin{array}{c}0.0004 \\
(0.0005)\end{array}$ & $\begin{array}{c}-0.0002 \\
(0.0004)\end{array}$ & $\begin{array}{l}-0.0005 \\
(0.0009)\end{array}$ & $\begin{array}{l}-0.0019 \\
(0.0064)\end{array}$ \\
\hline LSM production & $\begin{array}{c}-0.0406^{* * * *} \\
(0.0141)\end{array}$ & $\begin{array}{c}0.0048 \\
(0.0069)\end{array}$ & $\begin{array}{c}0.0018 \\
(0.0047)\end{array}$ & $\begin{array}{c}0.0135^{* *} \\
(0.0063)\end{array}$ & $\begin{array}{l}-0.0112 * \\
(0.0059)\end{array}$ & $\begin{array}{c}-0.0951^{* *} \\
(0.0473)\end{array}$ \\
\hline LSM research in ASM & $\begin{array}{c}0.0004 \\
(0.0006)\end{array}$ & $\begin{array}{l}-0.0000 \\
(0.0004)\end{array}$ & $\begin{array}{l}-0.0000 \\
(0.0002)\end{array}$ & $\begin{array}{c}-0.0001 \\
(0.0001)\end{array}$ & $\begin{array}{c}0.0000 \\
(0.0003)\end{array}$ & $\begin{array}{c}0.0011 \\
(0.0022)\end{array}$ \\
\hline LSM production in ASM & $\begin{array}{c}0.0004 \\
(0.0012) \\
\end{array}$ & $\begin{array}{c}0.0026^{* *} \\
(0.0013) \\
\end{array}$ & $\begin{array}{r}0.0015^{* *} \\
(0.0007) \\
\end{array}$ & $\begin{array}{c}0.0007 \\
(0.0010) \\
\end{array}$ & $\begin{array}{c}0.0021 * * * \\
(0.0008)\end{array}$ & $\begin{array}{c}0.0070 \\
(0.0095) \\
\end{array}$ \\
\hline $\begin{array}{l}\text { Observations } \\
\text { Cell FE }\end{array}$ & $\begin{array}{c}313,241 \\
\text { Yes }\end{array}$ & $\begin{array}{c}313,238 \\
\text { Yes }\end{array}$ & $\begin{array}{c}313,298 \\
\text { Yes }\end{array}$ & $\begin{array}{c}313,311 \\
\text { Yes }\end{array}$ & $\begin{array}{c}313,344 \\
\text { Yes }\end{array}$ & $\begin{array}{c}313,281 \\
\text { Yes }\end{array}$ \\
\hline Month FE & Yes & Yes & Yes & Yes & Yes & Yes \\
\hline
\end{tabular}

Notes: *** $\mathrm{p}<0.01, * * \mathrm{p}<0.05$, * $\mathrm{p}<0.1$; LPM estimations; Robust standard errors are clustered at the cell-level and reported in parentheses; In Columns (1) to (4) the dependent variables now measure the number of times an event occurred within a specific cell and month; In Column (5) we look at the monthly incidence of events with at least one fatality, while Column (6) looks at the number of times such events occurred in a specific cell and month. 


\section{Mineral prices}

We conduct a number of robustness checks relating to the mineral price interactions. First, we construct alternative measures of $\mathrm{ASM}_{\mathrm{i}} *$ price $_{\mathrm{t}}$, LSM Research $\mathrm{it}^{*}$ price $_{\mathrm{t}}$ and LSM Production ${ }_{\mathrm{it}}$ * price using world mineral prices with a one-month and a six-month lag. These alternative specifications consider that changes in conflict may not respond immediately to price changes. Moreover, they control for the fact that world mineral prices may be transmitted to local prices with some delay. The results are presented in Table A.11 and confirm the baseline findings.

As a second check, we collapse our dataset to cell-year observations. The dependent variables now count the number of months during which conflict events occurred in cell $\mathrm{i}$ and year $\mathrm{t}$, while the other variables represent the yearly average of their baseline counterparts. Table A.12 presents the results that are in line with the main results. 
TABLE A.11-USING LAGGED MINERAL PRICES

\begin{tabular}{|c|c|c|c|c|c|c|c|c|}
\hline & \multicolumn{4}{|c|}{ 1-month price lags } & \multicolumn{4}{|c|}{ 6-month price lags } \\
\hline & $\begin{array}{c}\text { Battles } \\
(1)\end{array}$ & $\begin{array}{c}\text { Violence } \\
(2)\end{array}$ & $\begin{array}{l}\text { Looting } \\
(3)\end{array}$ & $\begin{array}{l}\text { Riots } \\
(4)\end{array}$ & $\begin{array}{c}\text { Battles } \\
(5)\end{array}$ & $\begin{array}{c}\text { Violence } \\
(6)\end{array}$ & $\begin{array}{c}\text { Looting } \\
(7)\end{array}$ & $\begin{array}{c}\text { Riots } \\
(8)\end{array}$ \\
\hline ASM $*$ price & $\begin{array}{c}0.0044 * * * \\
(0.0016)\end{array}$ & $\begin{array}{c}0.0038 * * \\
(0.0013)\end{array}$ & $\begin{array}{c}0.0017 * * \\
(0.0007)\end{array}$ & $\begin{array}{c}0.0007 \\
(0.0005)\end{array}$ & $\begin{array}{c}0.0044 * * * \\
(0.0016)\end{array}$ & $\begin{array}{c}0.0034 * * \\
(0.0012)\end{array}$ & $\begin{array}{c}0.0015 * * \\
(0.0007)\end{array}$ & $\begin{array}{c}0.0007 \\
(0.0005)\end{array}$ \\
\hline LSM research * price & $\begin{array}{c}0.0016 \\
(0.0011)\end{array}$ & $\begin{array}{c}0.0007 \\
(0.0010)\end{array}$ & $\begin{array}{c}0.0003 \\
(0.0004)\end{array}$ & $\begin{array}{l}-0.0004 \\
(0.0002)\end{array}$ & $\begin{array}{c}0.0008 \\
(0.0010)\end{array}$ & $\begin{array}{c}0.0000 \\
(0.0009)\end{array}$ & $\begin{array}{c}0.0001 \\
(0.0004)\end{array}$ & $\begin{array}{c}-0.0006^{* *} \\
(0.0003)\end{array}$ \\
\hline LSM production * price & $\begin{array}{c}0.0025 \\
(0.0039)\end{array}$ & $\begin{array}{l}-0.0060 \\
(0.0043)\end{array}$ & $\begin{array}{c}0.0032 \\
(0.0030)\end{array}$ & $\begin{array}{c}0.0021 \\
(0.0028)\end{array}$ & $\begin{array}{c}0.0034 \\
(0.0046)\end{array}$ & $\begin{array}{l}-0.0033 \\
(0.0046)\end{array}$ & $\begin{array}{c}0.0035 \\
(0.0027)\end{array}$ & $\begin{array}{c}0.0014 \\
(0.0027)\end{array}$ \\
\hline LSM research & $\begin{array}{l}-0.0002 \\
(0.0011)\end{array}$ & $\begin{array}{l}-0.0001 \\
(0.0011)\end{array}$ & $\begin{array}{c}0.0001 \\
(0.0005)\end{array}$ & $\begin{array}{l}-0.0002 \\
(0.0004)\end{array}$ & $\begin{array}{c}0.0001 \\
(0.0011)\end{array}$ & $\begin{array}{c}0.0003 \\
(0.0011)\end{array}$ & $\begin{array}{c}0.0002 \\
(0.0005)\end{array}$ & $\begin{array}{l}-0.0002 \\
(0.0004)\end{array}$ \\
\hline LSM production & $\begin{array}{c}-0.0257 * * * \\
(0.0087)\end{array}$ & $\begin{array}{c}0.0028 \\
(0.0052)\end{array}$ & $\begin{array}{c}0.0015 \\
(0.0041)\end{array}$ & $\begin{array}{c}0.0121 * * \\
(0.0056)\end{array}$ & $\begin{array}{c}-0.0278 * * * \\
(0.0093)\end{array}$ & $\begin{array}{c}0.0014 \\
(0.0051)\end{array}$ & $\begin{array}{c}0.0013 \\
(0.0040)\end{array}$ & $\begin{array}{l}0.0124 * * \\
(0.0055)\end{array}$ \\
\hline LSM research in ASM & $\begin{array}{c}0.0003 \\
(0.0004)\end{array}$ & $\begin{array}{l}-0.0000 \\
(0.0004)\end{array}$ & $\begin{array}{c}0.0000 \\
(0.0002)\end{array}$ & $\begin{array}{l}-0.0001 \\
(0.0001)\end{array}$ & $\begin{array}{c}0.0003 \\
(0.0004)\end{array}$ & $\begin{array}{c}0.0000 \\
(0.0004)\end{array}$ & $\begin{array}{c}0.0000 \\
(0.0002)\end{array}$ & $\begin{array}{l}-0.0001 \\
(0.0001)\end{array}$ \\
\hline LSM production in ASM & $\begin{array}{l}-0.0002 \\
(0.0011)\end{array}$ & $\begin{array}{c}0.0026^{* *} \\
(0.0010)\end{array}$ & $\begin{array}{l}0.0015^{*} \\
(0.0009)\end{array}$ & $\begin{array}{c}0.0006 \\
(0.0008)\end{array}$ & $\begin{array}{l}-0.0004 \\
(0.0011)\end{array}$ & $\begin{array}{c}0.0026^{* * *} \\
(0.0010)\end{array}$ & $\begin{array}{l}0.0015^{*} \\
(0.0009)\end{array}$ & $\begin{array}{c}0.0006 \\
(0.0008)\end{array}$ \\
\hline Observations & 311,168 & 311,168 & 311,168 & 311,168 & 300,288 & 300,288 & 300,288 & 300,288 \\
\hline Cell FE & Yes & Yes & Yes & Yes & Yes & Yes & Yes & Yes \\
\hline Month FE & Yes & Yes & Yes & Yes & Yes & Yes & Yes & Yes \\
\hline
\end{tabular}

Notes: $* * * \mathrm{p}<0.01, * * \mathrm{p}<0.05, * \mathrm{p}<0.1$; LPM estimations; Conley (1999) standard errors in parentheses, allowing for spatial correlation within a $500 \mathrm{~km}$. radius and infinite serial correlation; We now estimate the ASM and LSM price interactions using lagged mineral prices; In the first Panel we use a one-month lag, in the second Panel we use a 6-month lag. 
TABLE A.12-CELL-YEAR OBSERVATIONS

\begin{tabular}{lcccc}
\hline \hline & $\begin{array}{c}\text { Battles } \\
(1)\end{array}$ & $\begin{array}{c}\text { Violence } \\
(2)\end{array}$ & $\begin{array}{c}\text { Looting } \\
(3)\end{array}$ & $\begin{array}{c}\text { Riots } \\
(4)\end{array}$ \\
\hline ASM * price & $0.0508^{* *}$ & $0.0454^{* * *}$ & $0.0206^{* *}$ & $0.0092^{*}$ \\
& $(0.0203)$ & $(0.0163)$ & $(0.0088)$ & $(0.0055)$ \\
LSM research * price & 0.0215 & 0.0138 & 0.0093 & -0.0046 \\
& $(0.0167)$ & $(0.0154)$ & $(0.0091)$ & $(0.0031)$ \\
LSM production * price & 0.0275 & -0.0853 & 0.0433 & 0.0102 \\
& $(0.0505)$ & $(0.0677)$ & $(0.0328)$ & $(0.0233)$ \\
LSM research & -0.0034 & -0.0024 & -0.0004 & -0.0027 \\
LSM production & $(0.0143)$ & $(0.0146)$ & $(0.0060)$ & $(0.0049)$ \\
& $-0.2976 * * *$ & 0.0289 & 0.0141 & $0.1631^{* *}$ \\
LSM research in ASM & $(0.0965)$ & $(0.0774)$ & $(0.0476)$ & $(0.0768)$ \\
& 0.0035 & -0.0009 & 0.0000 & -0.0019 \\
LSM production in ASM & $(0.0050)$ & $(0.0046)$ & $(0.0026)$ & $(0.0016)$ \\
& -0.0025 & $0.0344 * *$ & $0.0193 *$ & 0.0078 \\
Observations & $(0.0150)$ & $(0.0144)$ & $(0.0110)$ & $(0.0106)$ \\
Cell FE & 26,112 & 26,112 & 26,112 & 26,112 \\
Month FE & Yes & Yes & Yes & Yes \\
\hline
\end{tabular}

Notes: $* * * \mathrm{p}<0.01, * * \mathrm{p}<0.05, * \mathrm{p}<0.1$; LPM estimations; Conley (1999) standard errors in parentheses, allowing for spatial correlation within a $500 \mathrm{~km}$. radius and infinite serial correlation; We re-estimate equation (3) on cell-year observations; The dependent variables now count the number of months in which a conflict event occurred in cell $i$ and year $t$, while the other variables represent the yearly average of their baseline counterparts. 


\section{E. Distinguishing between state and non-state armed actors}

The ACLED database provides information on the actors involved in conflict events. This allows us to distinguish between state- and non-state armed actors. Overall, the Congolese army is mentioned as an actor in $44 \%$ of the conflict events in our database, including the large majority of battle events (81\%), $25 \%$ of looting events and $9 \%$ of violence against civilians. In our context, the Congolese army plays a dual role. On the one hand, they provide security to industrial mining companies (e.g. Geenen, 2014, 2013; Kilosho Buraye et al., 2017). On the other hand, they are "the most important armed actors illegally benefitting from artisanal mining” (Weyns, Hoex, and Matthysen 2016, 58). Artisanal mining sites in Eastern Congo are controlled by a plethora of relatively small groups of armed actors, with continuously changing allegiances, reorganizations and reincarnations (Stearns and Vogel 2015; Vogel and Mvano 2016; Weyns, Hoex, and Matthysen 2016). Besides the Congolese army, the armed presence consists of various rebel movements and Mai-Mai groups such as Raia Mutomboki, NDC and FDLR. ${ }^{37}$ Evidence indicates that rebel movements collide with each other and with factions of the Congolese army, while the latter may also back non-state armed actors. In the North-Kivu territory of Walikale, for instance, a new NDC faction (NDC-Rénové) split off from the NDC and clashed both with the NDC and the FDLR, supposedly with the support of Congolese army networks, taking over control of more than 80 artisanal mining sites between 2013-2015 (Vogel and Mvano, 2016; Weyns et al., 2016).

While the ACLED database does not allow us to tease out this dual role in detail, we can separately estimate our equations for conflict events with and without the involvement of state armed actors. In Table A.11 we present results using the same specification as Panel B of Table 3. The monthly conflict dummies in the uneven columns exclude all events that involve a state

\footnotetext{
37 Mai-Mai are community-based self-defense militia; NDC=Nduma Defence of Congo, also known as MaiMai Sheka; FDLR=Democratic Forces for the Liberation of Rwanda. For detailed information on armed actors in eastern DRC we refer to the various publications of the Congo Research Group and the Usalama project of the Rift Valley Institute (see e.g. Stearns, 2013a, 2013b; Stearns and Vogel, 2015; Vlassenroot, 2013; Vogel and Mvano, 2016).
} 
armed actor; thus excluding $81 \%$ of battles, $9 \%$ of violence against civilians and $25 \%$ of looting events. These are captured by the conflict dummies in the even columns, which only consider events that involve a state armed actor (including conflicts between state and non-state armed actors).

The results in Table A.11 confirm the main findings presented in the paper. We find that an increase in the value of ASM sites causes a rapacity effect: battles between non-state armed groups intensify, and there is a significant increase in violence against civilians and looting committed by these rebel movements (see columns 1,3 and 5). An increase in the value of ASM sites is further associated with an increase in battles between state and non-state armed actors, as well as an increase in violence against civilians committed by state armed actors (see columns 2 and 4). The start of LSM production activities is associated with a significant decrease in battles. In line with the protection effect hypothesized in the main paper, this is driven by a decrease in battles that involve a state armed actor (see columns 1 and 2). The protection effect suggests that the company and its 'protectors' - the Congolese army and the mining police outweigh other armed actors in terms of size and strength, thus creating a power asymmetry and making it less likely that they are challenged. When LSM companies expand their production activities in areas where artisanal miners are active, we find a significant increase in violence against civilians and looting committed by none-state armed actors (see columns 3 and 5). This is in line with the opportunity cost effect discussed in the main paper: non-state armed actors who previously profited from ASM may turn to alternative sources of finance by looting and attacking civilians. This effect is absent for state armed actors (see columns 4 and $6)$. 
TABLE A.13-DISTINGUISHING BETWEEN STATE AND NON-STATE ARMED ACTORS

\begin{tabular}{lcccccc}
\hline \hline & \multicolumn{2}{c}{ Battles } & \multicolumn{2}{c}{ Violence } & \multicolumn{2}{c}{ Looting } \\
& Non-state & State & Non-state & State & Non-state & State \\
\hline & $(1)$ & $(2)$ & $(3)$ & $(4)$ & $(5)$ & $(6)$ \\
\hline ASM * price & $0.0017^{* *}$ & $0.0027^{* *}$ & $0.0034^{* * *}$ & $0.0007^{* *}$ & $0.0015^{* *}$ & 0.0003 \\
& $(0.0007)$ & $(0.0012)$ & $(0.0012)$ & $(0.0004)$ & $(0.0006)$ & $(0.0003)$ \\
LSM research * price & 0.0002 & $0.0017^{*}$ & 0.0011 & -0.0001 & 0.0005 & -0.0000 \\
& $(0.0004)$ & $(0.0010)$ & $(0.0011)$ & $(0.0002)$ & $(0.0004)$ & $(0.0002)$ \\
LSM production * price & $-0.0016^{*}$ & 0.0041 & -0.0065 & 0.0014 & 0.0007 & $0.0026^{*}$ \\
& $(0.0009)$ & $(0.0035)$ & $(0.0048)$ & $(0.0014)$ & $(0.0018)$ & $(0.0015)$ \\
LSM research & -0.0001 & -0.0003 & 0.0001 & -0.0003 & 0.0002 & -0.0001 \\
& $(0.0003)$ & $(0.0009)$ & $(0.0010)$ & $(0.0002)$ & $(0.0004)$ & $(0.0002)$ \\
LSM production & -0.0008 & $-0.0250^{* * *}$ & 0.0020 & 0.0007 & 0.0015 & 0.0002 \\
& $(0.0013)$ & $(0.0075)$ & $(0.0046)$ & $(0.0017)$ & $(0.0032)$ & $(0.0016)$ \\
LSM research in ASM & -0.0001 & 0.0005 & -0.0000 & -0.0000 & -0.0000 & 0.0000 \\
& $(0.0001)$ & $(0.0003)$ & $(0.0003)$ & $(0.0001)$ & $(0.0002)$ & $(0.0001)$ \\
LSM production in ASM & -0.0000 & -0.0002 & $0.0025^{* * *}$ & 0.0004 & $0.0013 * *$ & 0.0004 \\
& $(0.0001)$ & $(0.0009)$ & $(0.0009)$ & $(0.0004)$ & $(0.0006)$ & $(0.0004)$ \\
\hline Observations & 313,344 & 313,344 & 313,344 & 313,344 & 313,344 & 313,344 \\
Cell FE & Yes & Yes & Yes & Yes & Yes & Yes \\
Month FE & Yes & Yes & Yes & Yes & Yes & Yes \\
\hline
\end{tabular}

Notes: $* * * \mathrm{p}<0.01, * * \mathrm{p}<0.05, * \mathrm{p}<0.1$; LPM estimations; Conley (1999) standard errors in parentheses, allowing for spatial correlation within a $500 \mathrm{~km}$. radius and infinite serial correlation; The dependent variables are monthly conflict dummies; In the uneven columns, the conflict dummies exclude events that involve a state armed actor; In the even columns, the conflict dummies only consider events that involve a state armed actor (including conflicts between state and non-state armed actors). 


\section{F. Controlling for rainfall shocks and seasons}

We control for rainfall as a proxy for exogenous shocks to agricultural income. In doing so, we follow a number of recent papers (Maystadt et al. 2014; Miguel et al. 2004; Parker and Vadheim 2017). On the one hand, an increase in agricultural income may raise the opportunity cost to join armed groups; on the other hand, it may increase armed groups' incentives to loot farmer communities. Heavy rainfall could also hinder mining activities and the movement of armed groups.

We use monthly rainfall data from the Climatic Research Unit (CRU - University of East Anglia). The spatial resolution of the CRU grid cells is larger than the grid cells in our analysis. In ArcGIS, we therefore assign to each grid cell the rainfall data from the nearest CRU centroid. The distance varies between 0 and 52 kilometers, with a mean of 8.3 and a standard deviation of 7.7 kilometers. First, we follow Maystadt et al. (2014) in calculating rainfall anomalies; these measure deviations from normal rainfall conditions for each cell-month observation. Specifically, the anomalies measure the monthly deviation from the long-term monthly mean, divided by the monthly long-term standard deviation. ${ }^{38}$ Second, to control for the possibility that seasonal patterns may matter, we follow the example of Parker and Vadheim (2017) in constructing variables to indicate wet and dry seasons. Specifically, based on the long-run monthly rainfall averages, we create two dummy variables that indicate the three driest and the three wettest months for each cell.

Table A.14 presents the results. All specifications control for contemporaneous and 12-month lagged rainfall anomalies, as well as cell-specific seasonal dummies.

\footnotetext{
38 The long-term average and standard deviation are calculated over the period 1997-2015.
} 
TABLE A.14-CONTROLLING FOR RAINFALL SHOCKS AND SEASONS

\begin{tabular}{lcccc}
\hline \hline & $\begin{array}{c}\text { Battles } \\
(1)\end{array}$ & $\begin{array}{c}\text { Violence } \\
(2)\end{array}$ & $\begin{array}{c}\text { Looting } \\
(3)\end{array}$ & $\begin{array}{c}\text { Riots } \\
(4)\end{array}$ \\
\hline ASM * price & $0.0038^{* *}$ & $0.0038^{* * *}$ & $0.0016^{* *}$ & 0.0007 \\
& $(0.0016)$ & $(0.0014)$ & $(0.0008)$ & $(0.0005)$ \\
LSM research * price & 0.0016 & 0.0009 & 0.0005 & -0.0003 \\
& $(0.0011)$ & $(0.0010)$ & $(0.0005)$ & $(0.0002)$ \\
LSM production * price & 0.0035 & -0.0071 & 0.0035 & 0.0024 \\
& $(0.0040)$ & $(0.0050)$ & $(0.0033)$ & $(0.0033)$ \\
LSM research & 0.0001 & 0.0006 & 0.0003 & -0.0004 \\
& $(0.0011)$ & $(0.0011)$ & $(0.0005)$ & $(0.0004)$ \\
LSM production & $-0.0274^{* * *}$ & 0.0061 & 0.0019 & $0.0125^{* *}$ \\
& $(0.0098)$ & $(0.0061)$ & $(0.0039)$ & $(0.0060)$ \\
LSM research in ASM & 0.0005 & 0.0000 & 0.0001 & -0.0001 \\
& $(0.0004)$ & $(0.0004)$ & $(0.0002)$ & $(0.0001)$ \\
LSM production in ASM & -0.0005 & $0.0026^{* *}$ & $0.0015 *$ & 0.0005 \\
& $(0.0011)$ & $(0.0011)$ & $(0.0008)$ & $(0.0008)$ \\
\hline Observations & 287,100 & 287,100 & 287,100 & 287,100 \\
Cell FE & Yes & Yes & Yes & Yes \\
Month FE & Yes & Yes & Yes & Yes \\
Rainfall anomalies L0-L12 & Yes & Yes & Yes & Yes \\
Dry season dummy & Yes & Yes & Yes & Yes \\
Wet season dummy & Yes & Yes & Yes & Yes \\
\hline
\end{tabular}

Notes: $* * * \mathrm{p}<0.01, * * \mathrm{p}<0.05, * \mathrm{p}<0.1$; LPM estimations; Robust standard errors are clustered at the cell-level and reported in parentheses; In every specification, we control for contemporaneous and 12 month lagged rainfall anomalies, as well as cell-specific seasonal dummies. 


\section{REFERENCES}

Anselin, Luc. 2002. "Under the Hood Issues in the Specification and Interpretation of Spatial Regression Models." Agricultural Economics 27 (3): 247-67.

Barr, Robert, and Ken Pease. 1990. "Crime Placement, Displacement, and Deflection.” Crime and Justice 12 (January): 277-318. https://doi.org/10.1086/449167.

Berman, Nicolas, Mathieu Couttenier, Dominic Rohner, and Mathias Thoenig. 2017. "This Mine Is Mine! How Minerals Fuel Conflicts in Africa." American Economic Review 107 (6): 1564-1610. https://doi.org/10.1257/aer.20150774.

Carisch, Enrico. 2012. "Conflict Gold to Criminal Gold: The New Face of Artisanal Gold Mining in Congo." Southern Africa Resource Watch.

Conley, T. G. 1999. "GMM Estimation with Cross Sectional Dependence." Journal of Econometrics 92 (1): 1-45. https://doi.org/10.1016/S0304-4076(98)00084-0.

Cuvelier, Jeroen, Steven Van Bockstael, Koen Vlassenroot, and Claude Iguma. 2014. "Analyzing the Impact of the Dodd-Frank Act on Congolese Livelihoods." SSRC Conflict Prevention and Peace Forum.

De Koning, Ruben. 2011. Conflict Minerals in the Democratic Republic of the Congo: Aligning Trade and Security Interventions. SIPRI Policy Paper, no. 27. Solna, Sweden: Stockholm International Peace Research Institute.

Geenen, Sara. 2012. "A Dangerous Bet: The Challenges of Formalizing Artisanal Mining in DRC." Resources $\quad$ Policy $37 \quad$ (3): $\quad 322-30$. https://doi.org/10.1016/j.resourpol.2012.02.004.

. 2013. "Dispossession, Displacement and Resistance: Artisanal Miners in a Gold Concession in South-Kivu, Democratic Republic of Congo." Resources Policy. https://doi.org/10.1016/j.resourpol.2013.03.004.

- 2014. "'Qui Cherche, Trouve' the Political Economy of Access to Gold Mining and Trade in South Kivu, DRC."

Hsu, Henda Y., and Graeme R. Newman. 2016. "The Situational Approach to Terrorism.” In The Handbook of the Criminology of Terrorism, edited by Gary LaFree and Joshua D. Freilich, 150-61. John Wiley \& Sons, Inc. https://doi.org/10.1002/9781118923986.ch9.

Johnson, Shane D., Rob T. Guerette, and Kate J. Bowers. 2012. "Crime Displacement and Diffusion of Benefits." In The Oxford Handbook of Crime Prevention, edited by David P. Farrington and Brandon C. Welsh.

Kilosho Buraye, Janvier, Nik Stoop, and Marijke Verpoorten. 2017. "Defusing the Social Minefield of Gold Sites in Kamituga, South Kivu. From Legal Pluralism to the ReMaking of Institutions?" Resources Policy 53 (September): 356-68. https://doi.org/10.1016/j.resourpol.2017.07.009.

Manski, Charles F. 1993. "Identification of Endogenous Social Effects: The Reflection Problem." The Review of Economic Studies 60 (3): 531-42. https://doi.org/10.2307/2298123. 
Maystadt, Jean-François, Giacomo De Luca, Petros G. Sekeris, and John Ulimwengu. 2014. "Mineral Resources and Conflicts in DRC: A Case of Ecological Fallacy?" Oxford Economic Papers 66: 721-49. https://doi.org/10.1093/oep/gpt037.

Miguel, Edward, Shanker Satyanath, and Ernest Sergenti. 2004. "Economic Shocks and Civil Conflict: An Instrumental Variables Approach.” Journal of Political Economy 112 (4): 725-53. https://doi.org/10.1086/421174.

Nickell, Stephen. 1981. "Biases in Dynamic Models with Fixed Effects." Econometrica 49 (6): 1417-26. https://doi.org/10.2307/1911408.

Parker, Dominic P., Jeremy D. Foltz, and David Elsea. 2016. "Unintended Consequences of Economic Sanctions for Human Rights. Conflict Minerals and Infant Mortality in the Democratic Republic of the Congo.” WIDER Working Paper 2016/124. UNU-WIDER.

Parker, Dominic P., and Bryan Vadheim. 2017. "Resource Cursed or Policy Cursed? US Regulation of Conflict Minerals and Violence in the Congo." Journal of the Association of Environmental and Resource Economists 4 (1): 1-49.

Raleigh, Clionadh, and Caitriona Dowd. 2016. "Armed Conflict Location and Event Data Project (ACLED) Codebook 2016.” ACLED.

Roodman, David. 2009. "How to Do Xtabond2: An Introduction to Difference and System GMM in Stata." The Stata Journal 9 (1): 86-136.

Seay, L. 2012. "What's Wrong with Dodd-Frank 1502? Conflict Minerals, Civilian Livelihoods, and the Unintended Consequences of Western Advocacy." 284. Working Paper. Center for Global Development.

Stearns, Jason. 2013a. Banyamulenge: Insurgency and Exclusion in the Mountains of South Kivu. Usalama Project. London: Rift Valley Institute. - 2013b. "Raia Mutomboki. the Flawed Peace Process in the DRC and the Birth of an Armed Franchise." Usalama Project. Rift Valley Institute.

Stearns, Jason, and Christoph Vogel. 2015. "The Landscape of Armed Groups in the Eastern Congo." Congo Research Group, Center on International Cooperation.

Stoop, Nik, Marijke Verpoorten, and Peter Van der Windt. 2018. "More Legislation, More Violence? The Impact of Dodd-Frank in the DRC." PLOS ONE 13 (8): e0201783. https://doi.org/10.1371/journal.pone.0201783.

UN Security Council. 2011. "Letter Dated 29 November 2011 from the Chair of the Security Council Committee Established Pursuant to Resolution 1533 (2004) Concerning the Democratic Republic of the Congo Addressed to the President of the Security Council." United Nations Security Council.

. 2012. "Letter Dated 12 November 2012 from the Chair of the Security Council Committee Established Pursuant to Resolution 1533 (2004) Concerning the Democratic Republic of the Congo Addressed to the President of the Security Council." United Nations Security Council.

USGS. 2013. "Mineral Commodity Summaries, 2013." United States Geological Survey.

—. 2015. "Mineral Commodity Summaries, 2015." United States Geological Survey. https://minerals.usgs.gov/minerals/pubs/mcs/2015/mcs2015.pdf. 
Vlassenroot, Koen. 2013. "South Kivu. Identity, Territory, and Power in the Eastern Congo." Usalama Project. Rift Valley Institute.

Vogel, Christoph, and Chrispin Mvano. 2016. "The Dogged Persistance of the FDLR." Congo Research Group (blog). March 4, 2016. http://congoresearchgroup.org/guest-blog-thedogged-persistence-of-the-fdlr/.

Weyns, Yannick, Lotte Hoex, and Ken Matthysen. 2016. "Analysis of the Interactive Map of Artisanal Mining Areas in Eastern DR Congo. 2015 Update.” Antwerp: IPIS.

Wimmer, Sarah Zingg, and Filip Hilgert. 2011. "Bisie. A One-Year Snapshot of the DRC's Principal Cassiterite Mine." International Peace Information Service.

World Bank. 2008. "Democratic Republic of Congo - Growth with Governance in the Mining Sector." 43402-ZR. World Bank. 